\title{
Food loss reduction from an environmental, socio-economic and consumer perspective - The case of the Swiss potato market
}

Christian Willersinn ${ }^{1,2^{*}}$, Patrik Mouron ${ }^{3}$, Gabriele Mack $^{1}$, Michael Siegrist $^{2}$

\begin{abstract}
Potatoes are one of the commodities with the highest loss shares along the entire supply chain. In the present study, we analyzed six potential loss reduction scenarios concerning their environmental-socio-economic sustainability compared with the current situation by using the "SustainOS" methodology. For this purpose, life cycle assessments, full-cost calculations and an online consumer survey were conducted. Environmental improvements through loss reduction were rather small and did not cross limits of significance, but the socioeconomic performance of the entire supply chain can be improved considerably. Pearson correlation coefficients and linear regression analyses were used to predict the influence of specific subjective items like the intention to avoid food loss, knowledge related to food loss and consumers' price sensitivity on the assigned preference. Results show that perceived risks, perceived inconvenience and the general acceptance of loss-reducing instruments influence consumers' preferences. Altogether, only three out of six tested scenarios seem realistic: selling unwashed potatoes in a lightproof box, selling unpacked potatoes, and improved quality sorting at farms. For two of the other scenarios, consumers significantly indicated their refusal even if losses decreased considerably, whereas the sixth scenario was unfavorable from a socio-economic perspective.
\end{abstract}

\section{Keywords}

Food waste; Sustainability assessment; Potato supply chain; SustainOS; Consumer preferences 


\section{Introduction}

Food losses not only lead to a waste of economic resources (de Lange and Nahman, 2015; Giuseppe et al., 2014; Katajajuuri et al., 2014; Venkat, 2011) but also to a waste of natural resources (Akkerman and Donk, 2008; FAO, 2013; Garnett, 2011; Richter and Bokelmann, 2016) and have ethical implications (Laroche et al., 2001; Stuart, 2009). Because of the complex consequences of food loss reduction strategies, they are often linked to the three parts of sustainable development: economics, social issues and environmental impacts (Eriksson et al., 2015). But empirical studies on sustainability improvements caused by food loss reduction strategies are rather scanty or mainly focus on just one dimension of the problem. To our best knowledge, there is no study published yet, that investigates the consequences of food loss and food loss reduction from the environmental, socioeconomic and consumer perspective simultaneously. The present study tries to close this gap and considers all three perspectives as we expect them all to be essential for the feasibility of food loss reduction. The necessity of a multi-dimensional view while searching for realizable loss reduction measures will be demonstrated with the aid of a previous study (Willersinn et al., 2016), in which the authors introduced six potential potato loss reduction scenarios and assessed them just from the environmental perspective. However, they neglected the socio-economic perspective and whether consumers might accept the measures suggested by the reduction scenarios. This might lead to decisions which could have undesired consequences for the socio-economic performance of the entire supply chain or which are not accepted by consumers. Therefore, the aim of the present study was to assess the overall sustainability from all three dimensions of the six food loss reduction scenarios which have already been environmentally assessed within Willersinn et al. (2016). For that purpose, we applied the SustainOS methodology (Mouron et al., 2012), which enables combining environmental and socio-economic attributes on various aggregation levels to an overall sustainability index (Bockstaller et al., 2008; Sadok et al., 2009). Furthermore, we evaluated consumers' preferences concerning the loss reduction measures with the aid of a consumer survey. In addition, we assessed factors which might influence consumers' preferences of specific loss reduction scenarios in order to get a feeling for feasible measures from the consumer perspective.

We chose fresh potatoes as an example as recent studies identified them to be one of the commodities with the highest loss rates (Beretta et al., 2012; Kranert et al., 2012; WWF, 2014). A previous study found that in Switzerland, 53\% of all fresh potatoes produced for direct human consumption get lost somewhere on their way from agricultural production to final consumption (Willersinn et al., 2015). In comparison, WRAP (2012) estimated for the UK that up to two-thirds of all produced fresh potatoes would not be consumed by humans. 
From 2011 to 2015, the average Swiss potato production destined for human consumption was 438,132 tonnes per year, matching approximately domestic demand. Circa $54 \%$ of the potatoes produced for human consumption are fresh potatoes, whereas $46 \%$ are processing potatoes (Swisspatat, 2015). In Switzerland, the average annual potato consumption per capita is circa $45 \mathrm{~kg}$ and relatively stable for the last 15 years (Swisspatat, 2015). However the world's average annual potato consumption in 2005 was with $31 \mathrm{~kg}$ per capita below the Swiss potato consumption but the European average was $88 \mathrm{~kg}$ per capita which was the highest proportion of all continents (FAO, 2015). Although the consumption in Switzerland is smaller than in many other European countries, potatoes are still the most favorable side dish compared to pasta (35$40 \mathrm{~kg} /($ capita*year)) and rice (20-25 kg/(capita*year)) (Swisspatat, 2015).

Both SustainOS methodology and consumer survey are described in detail in the following section of this article.

Results of the sustainability assessment and the factors influencing consumers' preferences are presented within the third section. Afterwards, the main findings are discussed and conclusions are drawn.

\section{Methods}

\subsection{Fresh potato losses and potential loss reduction scenarios}

Figure 1 shows a typical Swiss potato supply chain and demonstrates the mass flow of initially $100 \mathrm{~kg}$ fresh potatoes at farm stage including all losses and the reasons for their occurrence based on Willersinn et al. (2015). This current situation, which leads to a loss of $53 \mathrm{~kg}$ from $100 \mathrm{~kg}$ fresh potatoes, was used as the reference for our analysis.

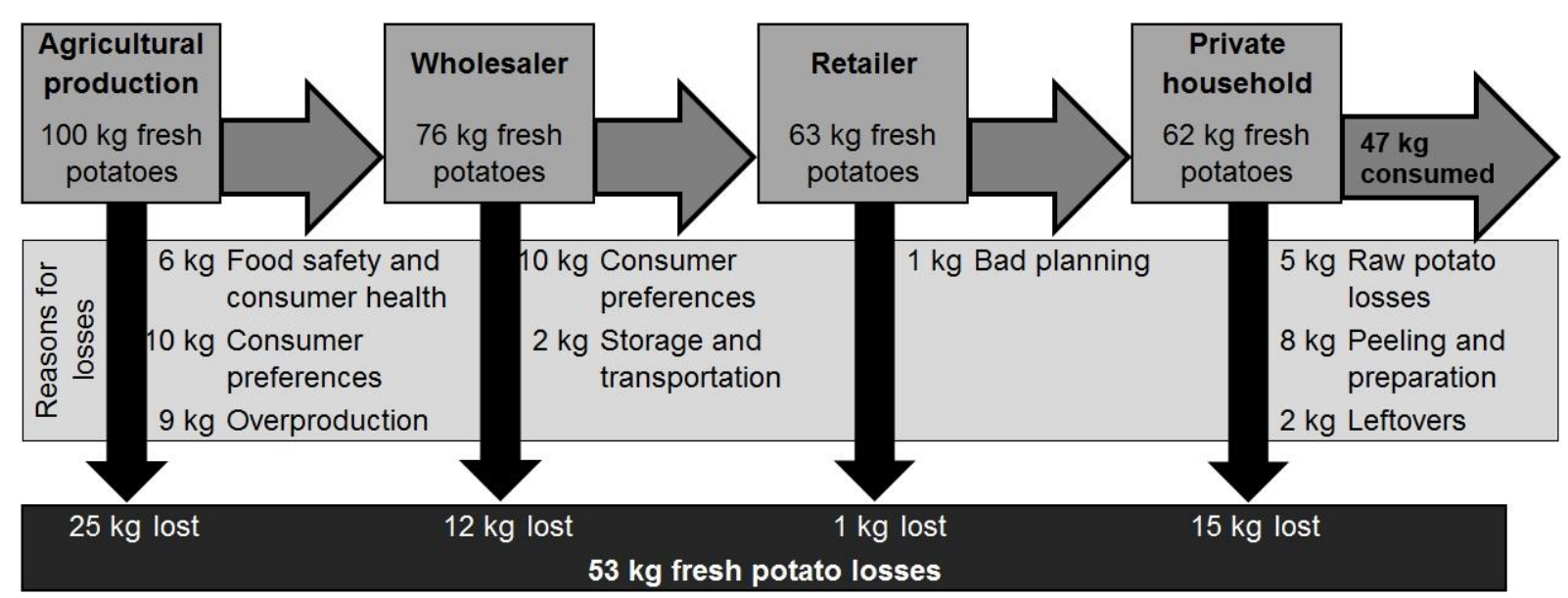

Figure 1: Typical Swiss fresh potato supply chain and the mass flow of initially $100 \mathrm{~kg}$ fresh potatoes harvested at farm stage (Willersinn et al., 2015).

Based on expert interviews with various stakeholders of the Swiss potato supply chain, Willersinn et al. (2016) defined four scenarios (A1, A3, A4, A5) consisting of several measures that might reduce potato losses. In 
addition, they included one scenario (A2) that might hold total losses constant but could improve the environmental performance of the whole supply chain. Furthermore, they combined four out of these five scenarios (A2 and A3 were conflictive) to get the most powerful loss reduction scenario (Mix). The six potential loss reduction scenarios are described in Table 1.

Table 1: Loss reduction scenarios, assumptions and assumed loss rates based on Willersinn et al. (2016). A = Agricultural production; $W=$ wholesaler; $R=$ retailer; $H$ = household.

\begin{tabular}{|c|c|c|c|c|c|c|c|}
\hline \multirow[t]{2}{*}{ Name } & \multirow[t]{2}{*}{ Description } & \multirow[t]{2}{*}{ Assumptions } & \multicolumn{5}{|c|}{$\begin{array}{l}\text { Loss rate (in } \% \text { of } \\
\text { total production) }\end{array}$} \\
\hline & & & $\mathrm{A}$ & $\mathrm{W}$ & $\mathrm{R}$ & $\mathrm{H}$ & $\sum$ \\
\hline Reference & \multicolumn{2}{|c|}{ Current situation (see Figure 1) } & 25 & 12 & 1 & 15 & 53 \\
\hline $\begin{array}{l}\text { A1: } \\
\text { Pesticide } \\
\text { against } \\
\text { wire } \\
\text { worms }\end{array}$ & $\begin{array}{l}\text { Goldor Bait (active } \\
\text { ingredient: fipronil) is } \\
\text { applied to combat wire } \\
\text { worms. Losses at farm stage } \\
\text { will stay constant (as } \\
\text { farmers will use the nascent } \\
\text { sorting capacity to sort out } \\
\text { other damages), but at } \\
\text { wholesalers losses due to } \\
\text { insufficient quality decrease. }\end{array}$ & $\begin{array}{l}\text { According to Keiser et al. (2012), } \\
\text { approximately } 7 \% \text { of the whole potato } \\
\text { stock gets lost due to wire worms or } \\
\text { the transmitted dry core disease. } \\
\text { Application of Goldor Bait might } \\
\text { decrease the total loss rate by five } \\
\text { percentage points [degree of efficiency } \\
70 \% \text { (Heger et al., 2010)]. }\end{array}$ & 25 & 7 & 1 & 15 & 48 \\
\hline $\begin{array}{l}\text { A2: } \\
\text { Improved } \\
\text { quality } \\
\text { sorting at } \\
\text { farms }\end{array}$ & $\begin{array}{l}\text { Before the potatoes are } \\
\text { delivered to wholesalers, } \\
\text { they are sorted more } \\
\text { intensively than currently at } \\
\text { farm stage. }\end{array}$ & $\begin{array}{l}80 \% \text { of all defected tubers will be } \\
\text { sorted out at farm stage [currently, } 60 \% \\
\text { of them are sorted out (Willersinn et } \\
\text { al., 2015)]. Losses increase at farm } \\
\text { stage but decrease at wholesalers. }\end{array}$ & 30 & 7 & 1 & 15 & 53 \\
\hline $\begin{array}{l}\text { A3: No } \\
\text { quality } \\
\text { sorting at } \\
\text { farms }\end{array}$ & $\begin{array}{l}\text { Farmers do not sort potatoes } \\
\text { anymore during harvest. } \\
\text { Quality sorting is completely } \\
\text { performed by wholesalers, } \\
\text { who might canalize various } \\
\text { qualities for different } \\
\text { customers. }\end{array}$ & $\begin{array}{l}\text { According to Willersinn et al. (2015), } \\
\text { some consumers might accept more } \\
\text { defects (e.g., deformities, under-sized } \\
\text { tubers) than others. By canalizing } \\
\text { various qualities for different } \\
\text { customers, losses might decrease by } \\
\text { four percentage points. }\end{array}$ & 9 & 24 & 1 & 15 & 49 \\
\hline $\begin{array}{l}\text { A4: } \\
\text { Selling } \\
\text { unwashed } \\
\text { potatoes in } \\
\text { a } \\
\text { lightproof } \\
\text { box }\end{array}$ & $\begin{array}{l}\text { Potatoes are not washed and } \\
\text { brushed anymore; } \\
\text { additionally, they are sold in } \\
\text { a lightproof paperboard } \\
\text { container. If potatoes are not } \\
\text { washed, they are storable for } \\
\text { a longer period. } \\
\text { Furthermore, light cannot } \\
\text { damage them. }\end{array}$ & $\begin{array}{l}\text { It is not possible to sort out all defected } \\
\text { tubers if they are not washed at } \\
\text { wholesaler stage. We assume that just } \\
\text { half of the defected tubers at } \\
\text { wholesalers can be sorted out. At } \\
\text { private households, losses might } \\
\text { increase by two percentage points due } \\
\text { to an increased share of defected tubers } \\
\text { in the containers. As the potatoes are } \\
\text { storable for a longer period, no more } \\
\text { losses due to bad planning at retailers } \\
\text { occur. }\end{array}$ & 25 & 6 & 0 & 17 & 48 \\
\hline $\begin{array}{l}\text { A5: } \\
\text { Selling } \\
\text { unpacked } \\
\text { potatoes }\end{array}$ & $\begin{array}{l}\text { Fresh potatoes are not } \\
\text { packed anymore. Consumers } \\
\text { pick and weigh their } \\
\text { potatoes at the supermarkets } \\
\text { as they are used to do with } \\
\text { many vegetables and fruits. }\end{array}$ & $\begin{array}{l}\text { At retailers, losses increase as people } \\
\text { pick their potatoes selectively. On the } \\
\text { other hand, no raw potato losses at } \\
\text { private households occur as consumers } \\
\text { purchase just as many potatoes as they } \\
\text { need. Peeling and preparation losses as } \\
\text { well leftovers are not affected and still } \\
\text { occur at private households. }\end{array}$ & 25 & 12 & 4 & 10 & 51 \\
\hline $\begin{array}{l}\text { Mix: } \\
\text { Combi- }\end{array}$ & $\begin{array}{l}\text { A pesticide is used to } \\
\text { combat wire worms (A1), }\end{array}$ & $\begin{array}{l}\text { All scenarios described above are } \\
\text { combined except A2 as it is conflictive }\end{array}$ & 9 & 12 & 4 & 13 & 38 \\
\hline
\end{tabular}




\begin{tabular}{|l|l|l|l|l|l|l|l|}
$\begin{array}{l}\text { nation of } \\
\text { loss } \\
\text { reduction } \\
\text { scenarios }\end{array}$ & $\begin{array}{l}\text { farmers do not sort potatoes } \\
\text { anymore (A3) and potatoes } \\
\text { are sold unwashed (A4) and } \\
\text { unpacked (A5). }\end{array}$ & $\begin{array}{l}\text { to A3, and A3 reduces losses more } \\
\text { effectively. }\end{array}$ & & & & & \\
\end{tabular}

\subsection{Environmental-socio-economic sustainability assessment methodology SustainOS}

For investigating the environmental and socio-economic consequences of the potato loss reduction scenarios simultaneously, the SustainOS methodology (Mouron et al., 2012) was applied which combines different attributes to an overall sustainability index. This methodology was developed to compare several plant protection strategies in fruit production (Mouron et al., 2012), but Mouron et al. (2016) already demonstrated that the method can also be applied for arable crops such as potatoes or wheat. The approach basically consists of five elements as described in Figure 2. In the following sections, we describe these five steps in detail with respect to the potato production system.

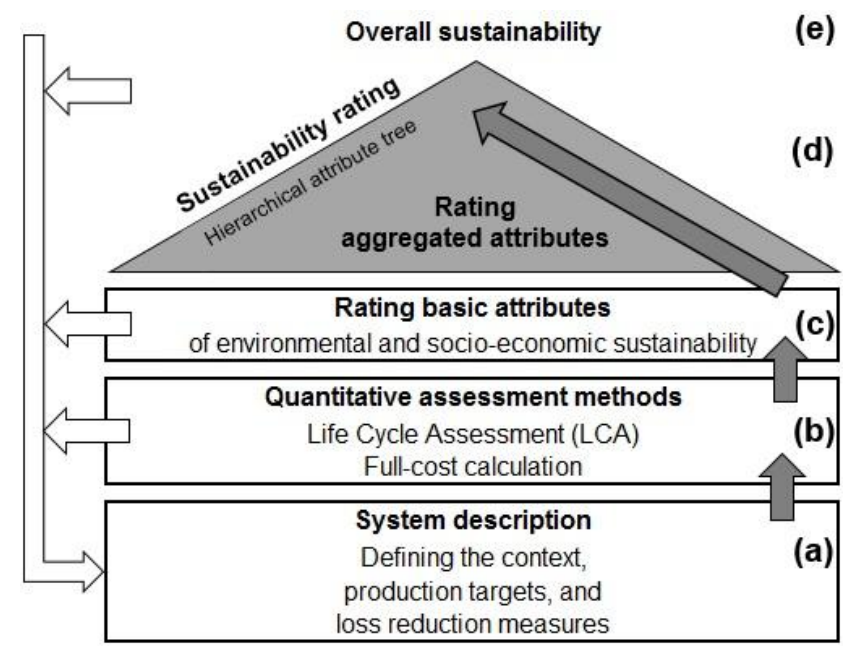

Figure 2: Scheme of the SustainOS methodology based on Mouron et al. (2012). Dark arrows mark the direction of the assessment process and white arrows show the feedback of results.

\subsubsection{System description (step a)}

For the assessment of realistic loss reduction scenarios, agronomic context parameters and production targets needed to be fixed (Table 2). The functional unit in the present study was $1 \mathrm{~kg}$ of consumed (boiled) fresh potatoes including all losses occurring on the way from agricultural production via wholesalers and retailers to private households. All inputs during an average production year were considered including fresh potato storage, transportation and meal preparation. The system boundary was the entire fresh potato supply chain excluding potential loss treatments as the aim of this study was to investigate the effect of loss reduction on the overall sustainability of the supply chain. We assumed an average fresh potato yield of 39.5 tonnes/ha (Agridea and 
Table 2: Definition of the context and targets.

\begin{tabular}{|c|c|}
\hline \multicolumn{2}{|r|}{ Context (valid for all scenarios) } \\
\hline Region & Whole Switzerland \\
\hline Cultivar and use & $\begin{array}{l}\text { Fresh potatoes (Bintje, Charlotte, Nicola) produced for direct human } \\
\text { consumption }\end{array}$ \\
\hline Yield & 39.5 tons/ha \\
\hline $\begin{array}{l}\text { Defected tubers within an average } \\
\text { potato stock }\end{array}$ & $21 \%$ \\
\hline Soil management & Plough \\
\hline Fertilizers: $\mathrm{N}, \mathrm{P}_{2} \mathrm{O}_{5}, \mathrm{~K}_{2} \mathrm{O}(\mathrm{kg} / \mathrm{ha})$ & $122,49,208$ \\
\hline $\begin{array}{l}\text { Pesticides: Fungicides, herbicides, } \\
\text { insecticides ( } \mathrm{g} / \mathrm{ha} \text { ) }\end{array}$ & $8,956,1,704,40$ \\
\hline $\begin{array}{l}\text { Water: Surface water, underground } \\
\text { water, tap water }\left(\mathrm{m}^{3} / \mathrm{ha}\right)\end{array}$ & $305,247,108$ \\
\hline \multicolumn{2}{|l|}{ Prices $(\mathrm{CHF} / 100 \mathrm{~kg})$} \\
\hline Producers receive & $\begin{array}{l}\text { 13.00 CHF for overproduction; } 5.00 \mathrm{CHF} \text { for delivered potatoes with } \\
\text { insufficient quality; } 44.81 \mathrm{CHF} \text { for delivered potatoes with sufficient } \\
\text { quality }\end{array}$ \\
\hline Wholesalers receive & $\begin{array}{l}117.00 \mathrm{CHF} \text { for delivered potatoes; } 5.00 \mathrm{CHF} \text { for rejected tubers } \\
\text { (sold as animal feed) }\end{array}$ \\
\hline Retailers receive & $175.00 \mathrm{CHF}$ for sold potatoes \\
\hline \multicolumn{2}{|l|}{ Transportation distances $(\mathrm{km})$ : } \\
\hline From farm to wholesaler & 30 (tractor and trailer) \\
\hline From wholesaler to retailer & 50 (truck) \\
\hline From retailer to household & 4.7 (car) \\
\hline Storage duration at wholesalers & 4 months \\
\hline Applied quality standard & Swiss trade regulations for potatoes (Swisspatat, 2013) \\
\hline \multicolumn{2}{|r|}{ Targets } \\
\hline Loss rate & Reduce total loss rate \\
\hline Environmental impacts & $\begin{array}{l}\text { Reduce environmental impacts of the entire Swiss potato supply } \\
\text { chain }\end{array}$ \\
\hline Consumer acceptance & Acceptable measures for reducing potato losses \\
\hline
\end{tabular}

The costs of the scenarios described in Table 1 were estimated with the aid of Swiss-specific standard calculation data (Agridea and FiBL, 2015), cultivation details (Keiser et al., 2007), and manufacturer's data (e.g., Heger et al. (2010)).

Life cycle assessment (LCA)

117 For investigating the environmental performances of the loss reduction strategies, LCA was applied. All direct and indirect emissions as well as the resource use related to fresh potatoes at all stages of the supply chain were considered. The design of this LCA followed the ISO 14040 (2006) norm and is already published within a previous study (Willersinn et al., 2016). Five important environmental impact categories were selected: demand for nonrenewable energy resources as an indicator of the resource use corresponding to food losses; the global 
warming potential (GWP); terrestrial and aquatic ecotoxicity as indicators of the environmental quality; and human toxicity to demonstrate the influence of food losses on human health.

\section{Full-cost calculation}

For socio-economic analysis, we carried out a full-cost calculation separately for each stage of the potato supply chain (see Appendix). At agricultural production, we applied the full-cost calculation scheme by Zorn (2014). At wholesaler stage, we considered the purchasing of fresh potatoes (sufficient quality and insufficient quality) based on the quality evaluation. Furthermore, we considered costs for storage and packing material based on Agridea and FiBL (2015) and costs for the amortization of storage and packing facilities. The interest and wages were based on specifications of one Swiss potato wholesaler with a market share of approximately $20 \%$. At retailer stage, the purchasing cost of fresh potatoes as well as transportation costs [based on BFS (2005)], labor costs, amortization and interest [estimations based on Migros (2015)] were considered. At private households, besides purchasing cost, we included transportation costs (BFS, 2005, 2015a) and energy costs for potato preparation (BFE, 2015; Sonesson et al., 2003). Specific costs for each loss reduction scenario (e.g., cost of the additional pesticide to combat wire worms $[\mathrm{A} 1 ;+350.00 \mathrm{CHF} / \mathrm{ha}]$; additional sorting costs [A2; $+358.40 \mathrm{CHF} / \mathrm{ha}$; reduced sorting costs $[\mathrm{A} 3 ;-896.00 \mathrm{CHF} / \mathrm{ha}$ ]; cost for the paperboard container [A4; +6.06 CHF/100 kg]; reduced cost for packaging [A5; -1.59 CHF/100 kg]) were derived from Agridea and FiBL (2015) and Heger et al. (2010).

From the full-cost assessment, the following socio-economic indicators were derived: net profit, total production cost, income variability, dramatic yield loss, invested capital and return on investment (Table 3). We chose these indicators based on Mouron et al. (2012) to represent the profitability, the production risk and the financial autonomy.

Table 3: Selected socio-economic indicators, formulas to calculate these indicators and some explanatory notes.

\begin{tabular}{|c|c|c|}
\hline Indicator & Formula & Explanatory notes \\
\hline Net profit & $\begin{aligned} & \text { Net profit } \text { Net profit } \\
&+ \text { Net } \text { profit }_{W} \\
&+ \text { Netprofit } \\
& R\end{aligned}$ & $\begin{array}{l}\text { As private households do not gain profit, we } \\
\text { decided to exclude the household stage } \\
\text { while calculating the net profit (total } \\
\text { revenue minus total cost) of the entire } \\
\text { supply chain. }\end{array}$ \\
\hline $\begin{array}{l}\text { Total } \\
\text { production } \\
\text { cost (PC) }\end{array}$ & $\begin{array}{c}P C_{S C}=P C_{A}+\left(P C_{W}-C_{o} P_{W}\right)+\left(P C_{R}\right. \\
\left.-C o P_{R}\right)\end{array}$ & $\begin{array}{l}\text { We excluded the cost of potato purchases as } \\
\text { these costs represent revenue for the } \\
\text { previous stage and expenses for the } \\
\text { subsequent stage, thus being eliminated. }\end{array}$ \\
\hline $\begin{array}{l}\text { Income } \\
\text { variability }\end{array}$ & $\begin{array}{c}\Delta I=I_{\text {Good }}-I_{\text {Bad }} \\
\text { with } I_{\text {Good } / \text { Bad }}=\frac{I_{A}+I_{W}+I_{R}+I_{H}}{\text { Consumption }} \\
\text { Good }=\text { Mean }_{\text {defects }}-\text { s.d.defects }\end{array}$ & $\begin{array}{l}\text { Keiser et al. (2007) provided data of a } \\
\text { sample of potato parcels and the quality of } \\
\text { the harvested potatoes for Switzerland. We } \\
\text { calculated the income per consumed kg } \\
\text { fresh potatoes across the entire supply chain }\end{array}$ \\
\hline
\end{tabular}




\begin{tabular}{|c|c|c|}
\hline & $B a d=$ Mean $_{\text {defects }}+s \cdot d_{\cdot d e f e c t s}$ & $\begin{array}{l}\text { of a "good" and a "bad" case, i.e., the mean } \\
\text { of defected tubers across all parcels minus } \\
\text { (good) and plus (bad) the standard deviation } \\
\text { of defected tubers. }\end{array}$ \\
\hline $\begin{array}{l}\text { Dramatic } \\
\text { yield loss }\end{array}$ & $\begin{array}{l}\text { Share of defected tubers per parcel } \\
>50 \%\end{array}$ & $\begin{array}{l}\text { Based on data provided by Keiser et al. } \\
(2007) \text {. }\end{array}$ \\
\hline $\begin{array}{l}\text { Invested } \\
\text { capital (IC) }\end{array}$ & $\begin{array}{c}I C_{S C}=I C_{A}+\left(I C_{W}-C_{o} P_{W}\right)+\left(I C_{R}-C_{o} P_{R}\right) \\
+\left(I C_{H}-C_{H} P_{H}\right)\end{array}$ & $\begin{array}{l}\text { We excluded the cost of potato purchases at } \\
\text { all stages as these costs do not result in } \\
\text { additional inputs into the system. The cost of } \\
\text { potato purchases at one stage act like } \\
\text { revenue for the previous stage. }\end{array}$ \\
\hline $\begin{array}{l}\text { Return on } \\
\text { investment } \\
(\mathrm{ROI})\end{array}$ & $R O I=\frac{\text { Net profit }}{I C}$ & \\
\hline
\end{tabular}

Abbreviations: $\mathrm{SC}=$ supply chain; $\mathrm{A}=$ agricultural production; $\mathrm{W}=$ wholesaler; $\mathrm{R}=$ retailer; $\mathrm{H}=$ household; $\mathrm{CoP}=$ cost of purchase $; \mathrm{I}=$ income $; \mathrm{IC}=$ invested capital; $\mathrm{ROI}=$ return on investment; $\mathrm{PC}=$ total production cost

\subsubsection{Aggregating environmental and socio-economic attributes (steps c-e)}

From Mouron et al. (2012), we adopted the hierarchical attribute tree to aggregate the selected attributes (Figure 3). All attributes at the bottom of the tree were called "basic attributes" and represented the results of the quantitative assessments. Those above the basic attributes were called "aggregated attributes". For aggregating basic attributes, the results of the quantitative assessments needed to be transformed into so-called "rating classes". Five rating classes were defined for rating the attributes: $-2=$ much worse than current situation; $-1=$ worse than current situation; $0=$ similar to current situation; $+1=$ better than current situation; $+2=$ much better than current situation. The percentages displayed in Figure 3 represent the weights for basic and aggregated attributes. In principle, we applied equal weights as long as no objective reasons for unequal ones occurred. Such unequal weights were used for the basic attributes "total production cost per kg" (20\%) and "net profit per $\mathrm{kg}$ " $(80 \%)$ because concerning the profitability, the total production cost per $\mathrm{kg}$ is of interest only if the net profit does not compensate for a change in cost. Furthermore, we weighted the production risk differently (67\% income variability; $33 \%$ dramatic yield loss) because for potato production, high income variability is much more probable than a dramatic yield loss (more than $50 \%$ of the whole potato stock is defected). Invested capital and return on investment were weighted with $33 \%$ and $67 \%$, respectively, because an increase in invested capital is not a problem as long as the profitability is satisfactory (Mouron et al., 2012). 


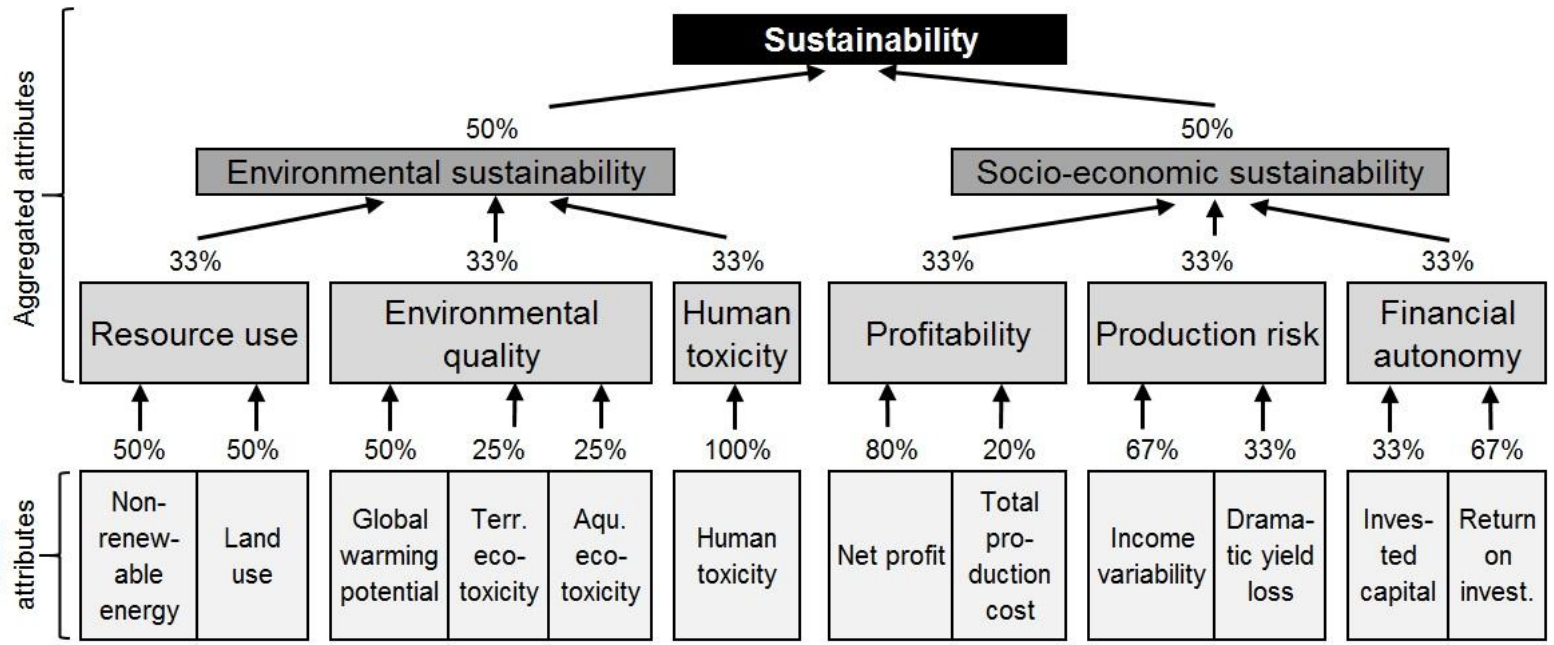

Figure 3: Hierarchical attribute tree according to Mouron et al. (2012) for assessing the sustainability of the fresh potato supply chain. Percentages are weights for aggregating attributes.

Table 4 shows the rating scales that defined how much each basic attribute needed to differ from the current situation so that it would be rated within a specific class. These limits for significant differences between the basic attributes compared with the reference situation were based on Nemecek et al. (2005) for the environmental indicators and on Mouron et al. (2016) for the socio-economic indicators. Like Mouron et al. (2012) and Nemecek et al. (2005), we used asymmetric rating scales for rating those basic attributes that performed only within positive numeric values (all observed environmental indicators).

Table 4: Limits for significant differences between basic attributes compared with the current situation based on Mouron et al. (2016) and Nemecek et al. (2005).

\begin{tabular}{|c|c|c|c|c|c|}
\hline $\begin{array}{l}\text { Rating } \\
\text { class }\end{array}$ & Meaning & $\begin{array}{l}\text { Resource use } \\
\text { attributes } \\
\text { (demand for } \\
\text { nonrenewable } \\
\text { energy } \\
\text { resources, } \\
\text { land demand, } \\
\text { GWP) }\end{array}$ & $\begin{array}{l}\text { Ecotoxicity } \\
\text { and human } \\
\text { toxicity } \\
\text { attributes }\end{array}$ & $\begin{array}{l}\text { Net profit, } \\
\text { return on } \\
\text { investment }\end{array}$ & $\begin{array}{l}\text { Total } \\
\text { production } \\
\text { cost, dramatic } \\
\text { yield loss, } \\
\text { income } \\
\text { variability, } \\
\text { invested } \\
\text { capital }\end{array}$ \\
\hline-2 & $\begin{array}{l}\text { Much worse than the current } \\
\text { situation }\end{array}$ & $>150 \%$ & $>250 \%$ & $<80 \%$ & $>120 \%$ \\
\hline-1 & $\begin{array}{l}\text { Worse than the current } \\
\text { situation }\end{array}$ & $117-150 \%$ & $150-250 \%$ & $80-95 \%$ & $105-120 \%$ \\
\hline 0 & $\begin{array}{l}\text { Similar to the current } \\
\text { situation }\end{array}$ & $86-117 \%$ & $67-150 \%$ & $95-105 \%$ & $95-105 \%$ \\
\hline+1 & $\begin{array}{l}\text { Better than the current } \\
\text { situation }\end{array}$ & $67-86 \%$ & $40-67 \%$ & $105-120 \%$ & $80-95 \%$ \\
\hline+2 & $\begin{array}{l}\text { Much better than the current } \\
\text { situation }\end{array}$ & $<67 \%$ & $<40 \%$ & $>120 \%$ & $<80 \%$ \\
\hline
\end{tabular}


An online survey was conducted in the German-speaking part of Switzerland to (1) assess consumers' general preference for the introduced loss reduction measures and (2) to analyze the factors which might influence the intensity of these preferences. Therefore, we used an internet panel from a commercial company (Respondi AG). Those participants who completed the questionnaire $(n=543)$ received a small financial compensation $(€ 1.50$ per questionnaire). For our analysis, we excluded those respondents who did not completely answer the questionnaire and those who completed the survey very quickly (less than half the median of total survey duration; $n=60$ ) as this might indicate an indifferent answering of questions (Siegrist et al., 2015). We used a quota sample with the variables age and gender. As a previous survey about potato losses in Swiss private households indicated that the age has a significant impact on loss quantities (Willersinn et al., 2015), we built three age groups. Table 5 shows the socio-demographics of the samples after excluding some respondents as explained above. The total sample consisted of 483 respondents. In comparison to the average Swiss public (BFS, 2016) our sample included a higher share of people living in rural areas (Swiss average 15\%) and agglomerations (Swiss average 22\%) and consequently fewer people from cities. As we excluded persons that were younger than 20 or older than 79 , our sample is not completely representative for the average Swiss public but the selected three age groups are the most relevant groups related to food purchases, consumption and disposal and cover 75\% of the Swiss population (Federal Statistical Office, 2014).

Table 5: Socio-demographics of the three created samples.

\begin{tabular}{|l|r|r|r|}
\hline Variable & $\begin{array}{l}\text { Age group 20-39 } \\
(n=146 ; \text { in \% })\end{array}$ & $\begin{array}{l}\text { Age group 40-59 } \\
(n=168 ; \text { in \% })\end{array}$ & $\begin{array}{l}\text { Age group 60-79 } \\
(n=169 ; \text { in \% })\end{array}$ \\
\hline Male & 47 & 50 & 50 \\
\hline Education & & & \\
No school certificate & 1.4 & 0 & 3.2 \\
Lower secondary school & 29.5 & 31.5 & 16.6 \\
General qualification for university entrance & 28.8 & 18.5 & 26.0 \\
Vocational academy, college education & 17.1 & 25.0 & 19.5 \\
Graduate and above & 22.6 & 24.4 & 27.2 \\
\hline Residential area & & & 32.5 \\
City & 38.4 & 29.9 & 40.2 \\
Agglomeration & 32.2 & 28.1 & 41.9 \\
Rural area & 29.5 & & \\
\hline
\end{tabular}

\subsubsection{Consumers' general preferences for the loss reduction strategies}

In the survey, the current potato loss situation in Switzerland was described in understandable, laypeople's terms (i.e., "approximately $53 \%$ of all produced fresh potatoes are lost somewhere on their way from field to plate. This equals about 5,300 trucks of fresh potatoes each year"). Afterwards, we described three of the six loss reduction scenarios introduced in Table 1. We excluded A2 and A3 from the consumer survey as in these two 
scenarios, solely the sorting process is varied and we assumed that consumers do not care whether farmers sort out more intensively (A2) or not at all (A3) as long as the potato quality for consumers remains constant. In addition, we excluded the scenario Mix as it is a combination of the other scenarios. If consumers strictly reject one of the single scenarios, we can assume that they might also reject the combined scenario.

The benefits and risks of each loss reduction scenario were described [e.g., for scenario A1: "The pesticide against wire worms is used in some European countries but is actually prohibited in Switzerland as it bears high environmental risks (bees, birds) by improper use", and: "Through the use of this pesticide, the total annual potato losses in Switzerland could be reduced by 500 truckloads"; for scenario A4: "If potatoes were to be sold unwashed, it would not be possible to sort out all defected tubers, so some defected tubers might be sold in the paperboard containers", and: "If potatoes were to be sold unwashed and in lightproof containers, the total annual potato losses in Switzerland could be reduced by 500 truckloads"; for scenario A5: "If potatoes were to be sold unpacked, you would have to pack and weigh them yourself, but the total annual potato losses might be reduced by 200 truckloads"]. For the first purpose of the consumer survey (assessing the general preference of each loss reduction measure), respondents indicated their preference for each specific scenario compared with the current situation by using a slider (no initial value provided). Each slider ranged from 0 (strong preference for the current situation) to 100 (strong preference for the suggested loss reduction scenario) and was located directly after the questions focusing on one scenario. Survey data were analyzed using SPSS (IBM SPSS Statistics Version 23). Analysis of variance (ANOVA) was used to analyze mean differences between the indicated preferences for each scenario.

\subsubsection{Factors influencing consumers' preferences}

For the second purpose of the consumer survey (assessing the factors that influence consumers' preference) we built a theoretical model consisting of factors which might influence consumers' preferences for a specific loss reduction scenario (Figure 4) based on recently published studies on consumers' waste behavior (Graham-Rowe et al., 2014; Stancu et al., 2016; Visschers et al., 2016). Respondents needed to answer several questions referring to the described scenario (see Appendix) on a 5-point response scale, which ranged from 1 (fully agree) to 5 (do not agree at all) after each scenario description. In addition, some standard socio-demographic questions were included in the survey as well as questions about respondents' knowledge about food loss and general intention to avoid food losses (also on a 5-point response scale as described above). 


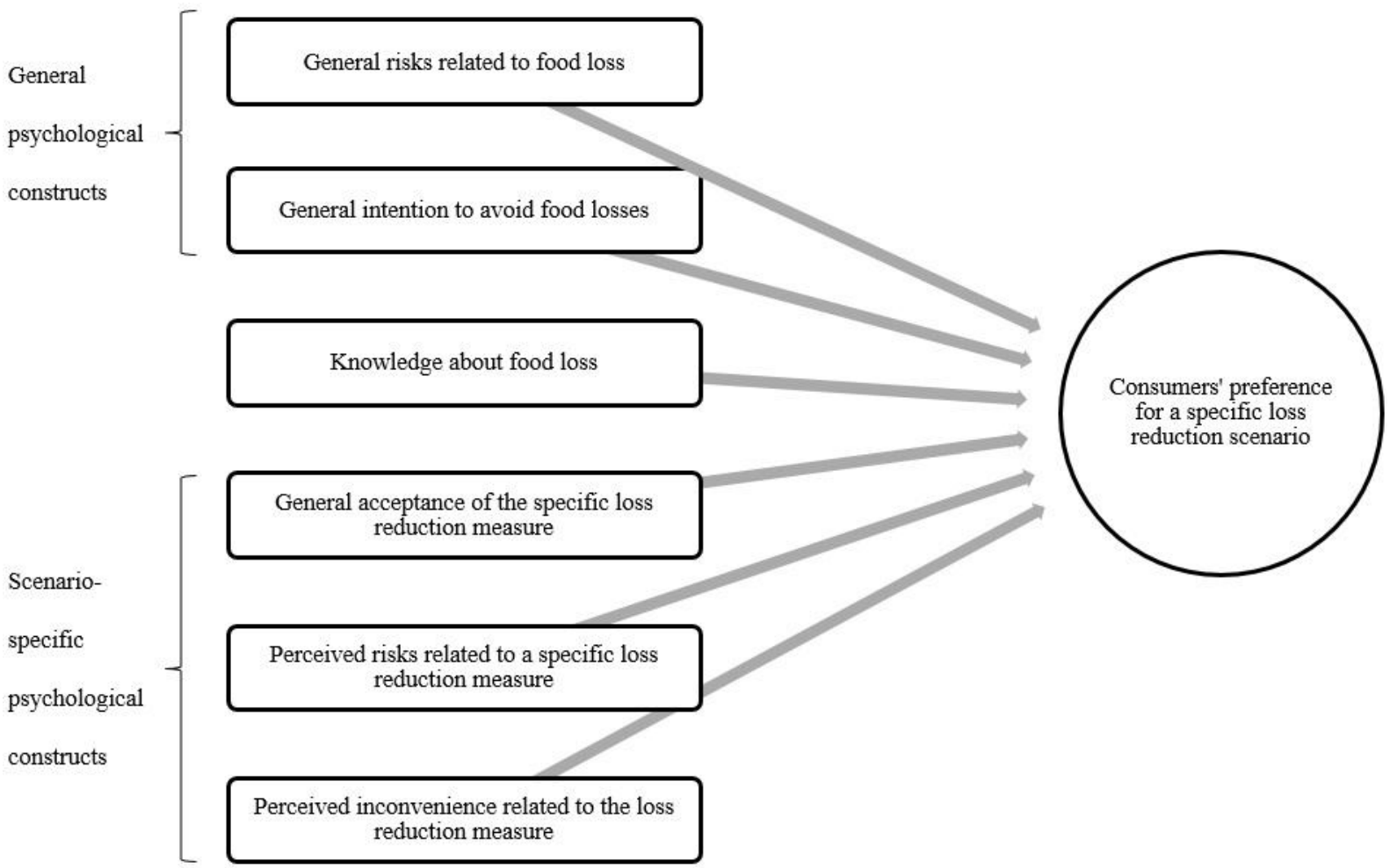

Figure 4: Factors which might influence consumers' preferences for a specific loss reduction scenario.

We assigned each item of the scenario-specific questions to one of the factors shown in Figure 4 and calculated Cronbach's $\alpha$ to check the internal reliability of the scales. If the internal reliability of the scale was acceptable, we calculated the mean over the items for each construct for further analyses (see Appendix). To indicate respondents' knowledge, we calculated the mean over 11 items on knowledge related to food loss (see Appendix). We calculated Pearson correlation coefficients between the formed constructs and respondents' preference for the suggested scenario to analyze bivariate relations between the variables and to check for multicollinearity. Linear regression analyses (used method: forced entry) were conducted to examine the predictors of respondents' preference (dependent variable, indicated with the aid of the slider mentioned above) for the suggested scenario.

\section{Results}

\subsection{Sustainability assessment results}

\subsubsection{The environmental perspective}

Figure 5 presents the life cycle impact assessment (LCIA) results of the six investigated loss reduction scenarios relative to the reference situation, based on the results of Willersinn et al. (2016). The differences between the current situation and the loss reduction scenarios A1-A5 were rather small for all observed impact categories 

current situation.

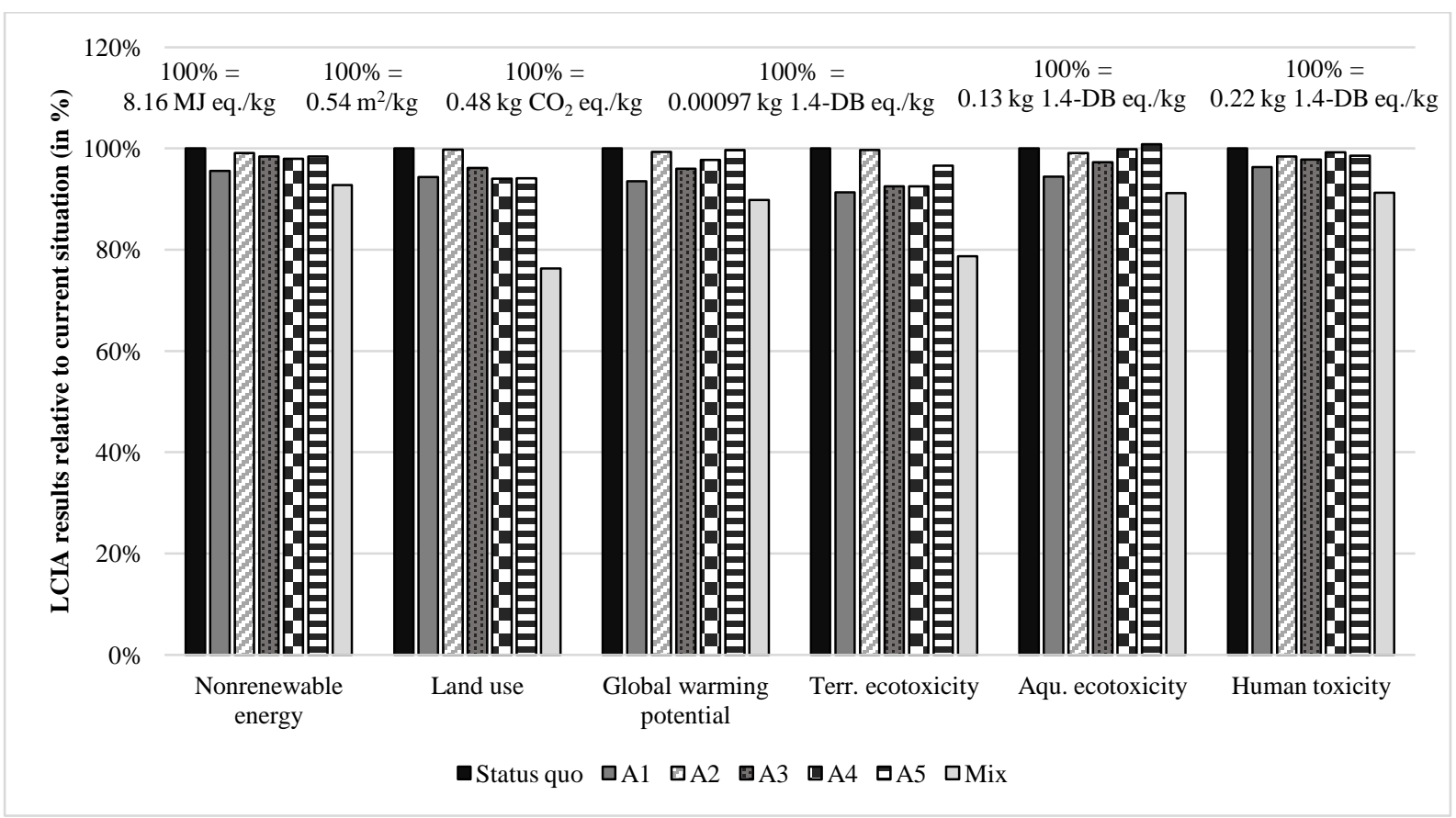

Figure 5: Life cycle impact assessment (LCIA) results of the loss reduction scenarios relative to the current situation. A1 = Pesticides against wire worms; $A 2=$ improved quality sorting at farms; $A 3=$ no quality sorting at farms; A4 = selling unwashed potatoes in a lightproof box; A5 = selling unpacked potatoes; Mix = combination of scenarios. Current situation = $100 \%$.

\subsubsection{The socio-economic perspective}

The results of the quantitative socio-economic assessment of the loss reduction scenarios are presented in Figure 6. For the reference situation, the net profit of $1 \mathrm{~kg}$ consumed fresh potatoes along the entire supply chain added up to $0.28 \mathrm{CHF} / \mathrm{kg}(-0.08 \mathrm{CHF} / \mathrm{kg}$ at agricultural production; $0.07 \mathrm{CHF} / \mathrm{kg}$ at wholesaler stage; $0.29 \mathrm{CHF} / \mathrm{kg}$ at retailer stage). In the loss reduction scenarios A1, A2, A4 and Mix, the net profit per $\mathrm{kg}$ consumed potatoes increased by $10 \%, 8 \%, 16 \%$ and $41 \%$, respectively. When no quality sorting at farm stage took place (A3), the total net profit decreased by $9 \%$ because more potatoes with insufficient quality had to be handled by wholesalers. When potatoes were traded unpacked (A5), the total net profit decreased by $16 \%$ due to increased losses at retailer stage.

Between the loss reduction scenarios, the total production cost did not vary greatly $(2.62 \mathrm{CHF} / \mathrm{kg}$ in the reference situation). It differed between $-7 \%$ and $+2 \%$ for the single measure scenarios (A1-A5) and by $-14 \%$ for the combined scenario (Mix) relative to the reference situation. Additional costs (e.g., for pesticide use, packaging, sorting) were overcompensated by an improved efficiency through loss reduction. 
Concerning the income variability $(0.35 \mathrm{CHF} / \mathrm{kg}$ in the reference situation), all loss reduction scenarios improved the current situation with the exception of A3 (+45\%). If farmers did not sort potatoes anymore (A3), larger quantities of potatoes needed to be transported and stored, which was more cost intensive. Especially a high share of defected tubers in a delivery caused high needless costs, whereas a low share of defected tubers saved money at farm stage (no sorting costs) and at wholesaler stage (no unnecessary transportation and storage costs). Thus, the earlier defected tubers were rejected (or avoided), the lower was the income variability. Improved pest control in the scenarios A1 and Mix reduced the probability of a dramatic yield loss by $50 \%$. In both cases, the share of potato parcels with more than $50 \%$ defected tubers decreased from $2 \%$ of all parcels to 1\%. For all other scenarios, no changes occurred concerning this indicator.

The results for the invested capital $(2.42 \mathrm{CHF} / \mathrm{kg}$ in the reference situation) were similar to those of the total production cost, because both indicators basically focused on costs and did not take into account related benefits. The return on investment (ROI: 0.12 in the reference situation) increased for all scenarios except for A3 and A5 $(-11 \%$ and $-9 \%$, respectively). Again, the scenario Mix scored best (ROI: 0.19). In addition, A1 (+13\%), A2 $(+10 \%)$ and A4 (+15\%) resulted in a better ROI than the current situation.

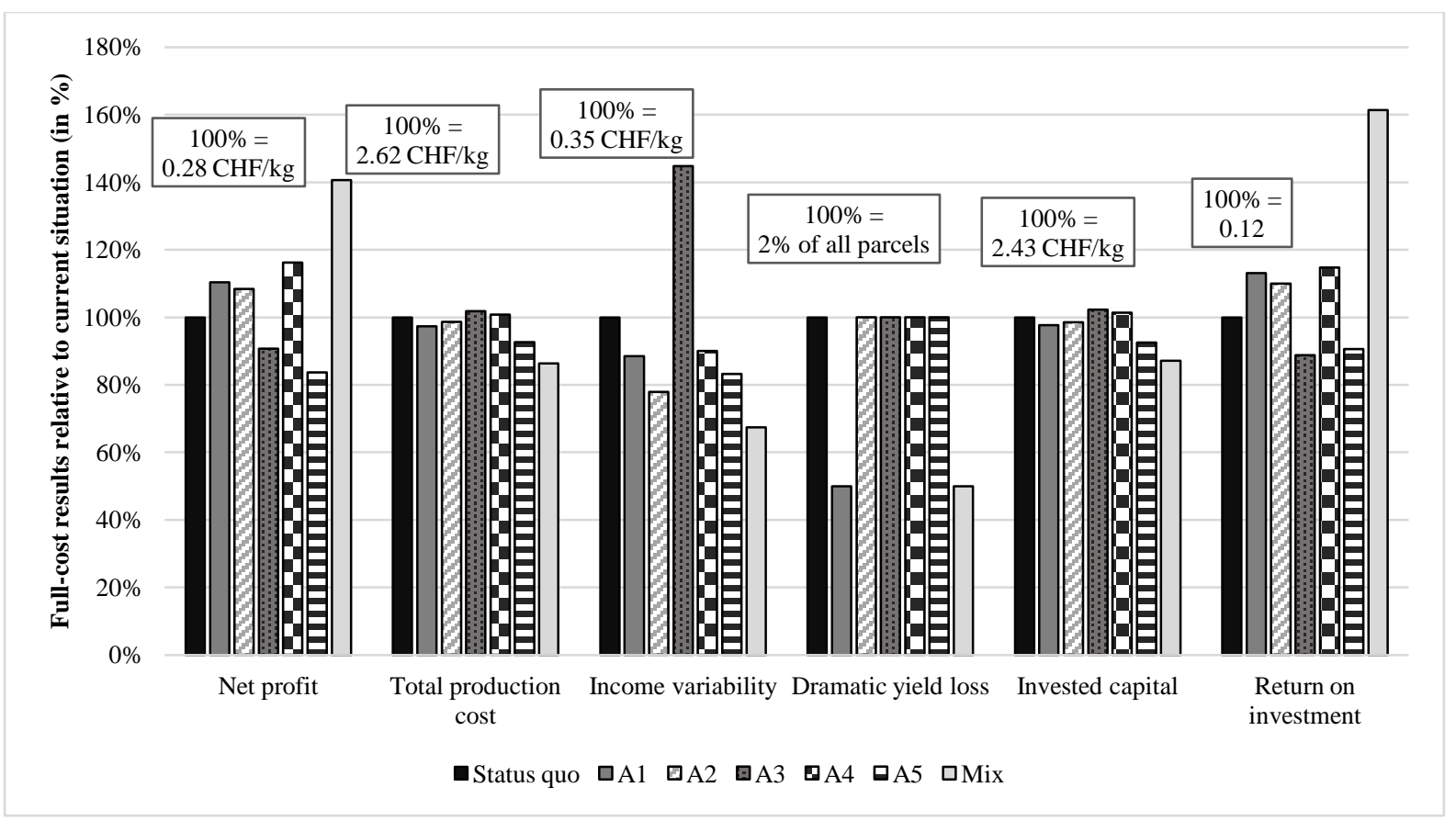

Figure 6: Full-cost calculation results of the loss reduction scenarios relative to the current situation (in \%). Al = Pesticides against wire worms; $A 2=$ improved quality sorting at farms; $A 3=$ no quality sorting at farms; $A 4=$ selling unwashed potatoes in a lightproof box; A5 = selling unpacked potatoes; Mix = combination of scenarios. Current situation $=100 \%$.

\subsubsection{The consumer perspective}

Table 6 shows the results of the preference rating. The means of the indicated preferences for each scenario were significantly different among the scenarios at the $95 \%$ level. Scenario A1's average score was below $50(\mathrm{M}=$ 
36.69; $\mathrm{SD}=23.80$ ), which means that the respondents preferred the current situation if they had to decide between these two options. No significant differences occurred between age groups or gender concerning their preference rating results for the three investigated scenarios.

Table 6: Survey results (means, $M)$ for the preference rating of each scenario including standard deviations (SD) and the $95 \%$ confidence intervals.

\begin{tabular}{|l|c|c|c|c|c|}
\hline \multicolumn{1}{|c|}{ Variable } & $n$ & M & SD & \multicolumn{2}{c|}{ 95\% confidence interval } \\
\cline { 4 - 6 } & & & 23.80 & 34.56 & 38.82 \\
\hline $\begin{array}{l}\text { Preference for A1 against preference for } \\
\text { current situation (scale from 0-100) }\end{array}$ & 483 & 36.69 & & 57.34 & 61.89 \\
\hline $\begin{array}{l}\text { Preference for A4 against preference for } \\
\text { current situation (scale from 0-100) }\end{array}$ & 483 & 59.61 & 25.47 & 67.20 & 71.61 \\
\hline $\begin{array}{l}\text { Preference for A5 against preference for } \\
\text { current situation (scale from 0-100) }\end{array}$ & 483 & 69.41 & 24.66 & & Upper \\
\hline
\end{tabular}

Note: Preference for each scenario rated with a slider from $0=$ strong preference for current situation to $100=$ strong preference for the alternative scenario. A1 = Pesticides against wire worms; A4 = selling unwashed potatoes in a lightproof box; A5 = selling unpacked potatoes.

The sustainability rating results for the aggregated attributes "resource use", "environmental quality", "human toxicity", "profitability", "production risk" and "financial autonomy" are presented in Figure 7. The observed variations between the loss reduction scenarios and the current situation in the quantitative LCIA results did not exceed the defined limits of significance, and thus, almost all environmental basic attributes were categorized to rating class 0 (similar to the current situation). Only the "land demand" in the scenario Mix crossed the class limit and was categorized as +1 (better than the current situation). The observed socio-economic indicators showed greater variabilities. The scenario A3 scored worse than the current situation for all three aggregated socio-economic attributes, whereas A5 scored worse for profitability and financial autonomy but better for the production risk. All other loss reduction scenarios resulted in a better performance for all three aggregated socioeconomic attributes than the reference situation. The overall sustainability index of the scenarios A5 $(-0.05)$ and A3 (-0.468) were negative, whereas A1 (+0.467), A2 (+0.468), A4 (+0.357) and Mix (+0.995) were more sustainable than the reference situation in the context of this study. Although the sustainability index of A1 and be feasible. All other scenarios would be accepted by consumers. 


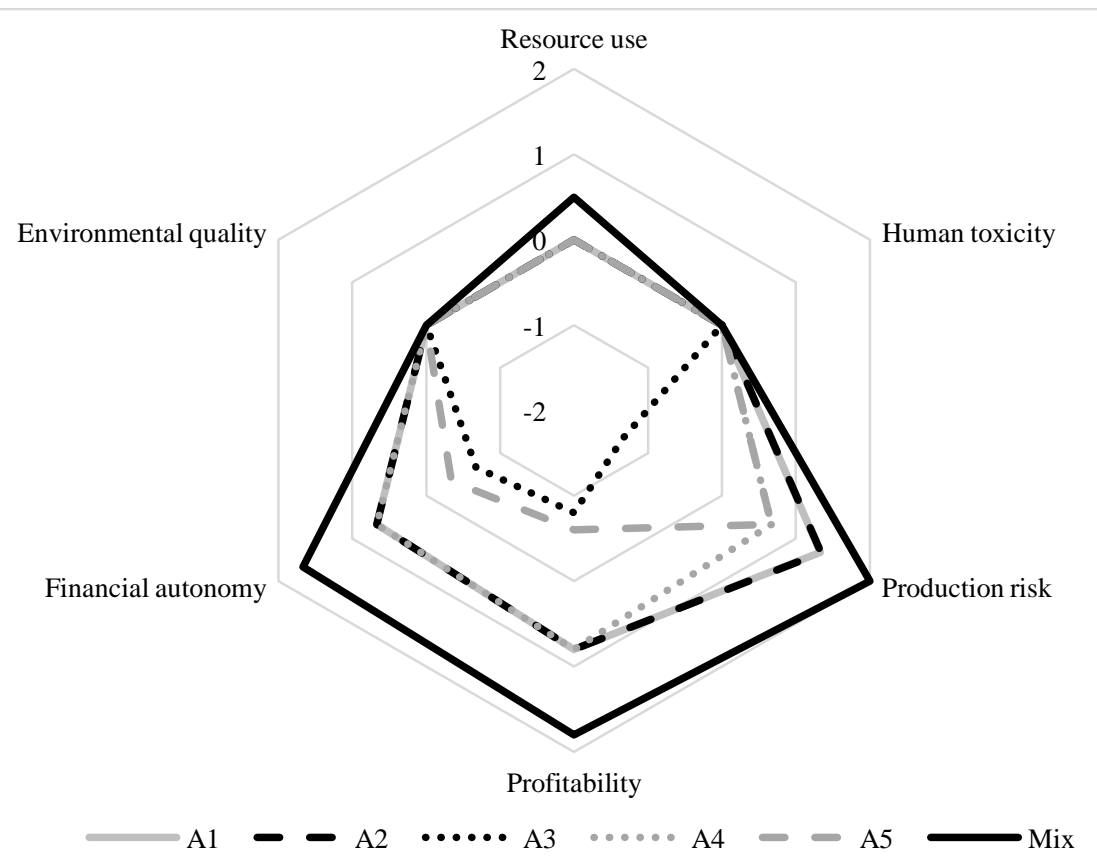

Figure 7: Rating results for the aggregated attributes resource use, environmental quality, human toxicity, profitability, production risk and financial autonomy. Rating classes: $-2=$ much worse than current situation; $-1=$ worse than current situation; $0=$ similar to current situation; $+1=$ better than current situation; $+2=$ much better than current situation. Al= Pesticides against wire worms; $A 2=$ improved quality sorting at farms; $A 3=$ no quality sorting at farms; $A 4=$ selling unwashed potatoes in a lightproof box; A5 = selling unpacked potatoes; Mix = combination of scenarios.

\subsection{Factors influencing consumers' scenario-specific preferences}

First, we assessed with the aid of several items the respondents' general intention to avoid food loss (see Appendix). On average, the intention to avoid food loss was rather high $(\mathrm{M}=1.45 ; \mathrm{SD}=0.59$; on a 5-point Likert scale; intention decreased from 1 to 5). Furthermore, the respondents showed acceptable general knowledge related to food loss $(\mathrm{M}=2.07$; $\mathrm{SD}=0.43$; knowledge decreased from 1 to 5$)$. The "general risks of food loss" were rather low-rated by the respondents $(\mathrm{M}=3.68 ; \mathrm{SD}=0.94$; risk decreased from 1 to 5$)$. The internal reliabilities of the scales we used to assess the general constructs (intention to avoid food loss: Cronbach's $\alpha=0.866$; general risks related with food loss: Cronbach's $\alpha=0.547)$ were acceptable. Also the scenario-specific constructs for A1 (pesticides against wire worms; acceptance: Cronbach's $\alpha=0.738$; inconvenience: Cronbach's $\alpha=0.513$; perceived pesticide risks: Cronbach's $\alpha=0.540$ ), A4 (selling unwashed potatoes in a lightproof box; acceptance: Cronbach's $\alpha=0.775$; inconvenience: Cronbach's $\alpha=0.677$; perceived risks of scenario A4: Cronbach's $\alpha=0.571$ ) and A5 (selling unpacked potatoes; acceptance: Cronbach's $\alpha=$ 0.695; inconvenience: Cronbach's $\alpha=0.747$; perceived risks of scenario A5: consists of just one variable) revealed acceptable internal reliabilities of the scales. 

scenario-specific constructs as well as the general constructs showed significant correlations for almost all constructs (see Appendix; Table A3-Table A5). The only exception was the general intention to avoid food loss which was not significantly correlated with the preference for scenario A4. Furthermore, in all three cases, consumers' price sensitivity was not significantly correlated with the preferences for the loss reduction scenarios.

Table 7: Results of the linear regression analyses of the preference for the three loss reduction scenarios. $B=$ unstandardized regression coefficients; $S E=$ standard errors; $\beta=$ standardized regression coefficients.

\begin{tabular}{|c|c|c|c|c|c|c|c|c|c|}
\hline \multirow[t]{2}{*}{ Variable } & \multicolumn{3}{|c|}{$\begin{array}{c}\text { Scenario A1 (pesticides against } \\
\text { wire worms) }\end{array}$} & \multicolumn{3}{|c|}{$\begin{array}{l}\text { Scenario A4 (selling unwashed } \\
\text { potatoes in a lightproof box) }\end{array}$} & \multicolumn{3}{|c|}{$\begin{array}{l}\text { Scenario A5 (selling unpacked } \\
\text { potatoes) }\end{array}$} \\
\hline & $\mathrm{B}$ & SE & $\beta$ & $\mathrm{B}$ & $\mathrm{SE}$ & $\beta$ & $\mathrm{B}$ & SE & $\beta$ \\
\hline (Constant) & 76.50 & 13.05 & **** & 28.28 & 21.09 & & 40.89 & 15.47 & *** \\
\hline Age group & 0.21 & 1.15 & 0.007 & -1.86 & 1.35 & -0.058 & -1.30 & 1.31 & -0.043 \\
\hline Gender $^{1}$ & -0.06 & 1.80 & -0.001 & 0.42 & 2.13 & 0.008 & 0.52 & 2.02 & 0.011 \\
\hline Household size & -0.64 & 0.57 & -0.043 & -0.20 & 0.66 & -0.013 & -0.25 & 0.64 & -0.016 \\
\hline Residential area ${ }^{2}$ & 1.84 & 1.09 & 0.064 & 2.10 & 1.29 & 0.068 & 0.66 & 1.23 & 0.022 \\
\hline Education & -01.24 & 0.77 & -0.062 & -01.13 & 0.90 & -0.053 & 0.38 & 0.85 & 0.019 \\
\hline $\begin{array}{l}\text { Acceptance of the } \\
\text { scenario }\end{array}$ & 13.70 & 1.51 & $0.494 * * *$ & 8.92 & 3.16 & $0.193^{* *}$ & 9.17 & 1.68 & $0.285^{* * *} *$ \\
\hline Inconvenience & -0.27 & 1.51 & -0.008 & -11.28 & 2.38 & $-0.316^{* * *}$ & -10.66 & 1.97 & $-0.314 * * *$ \\
\hline $\begin{array}{l}\text { Perceived } \\
\text { scenario risks }\end{array}$ & -05.48 & 1.55 & $-0.158^{* * * *}$ & -4.52 & 1.74 & $-0.161^{*}$ & -2.25 & 1.08 & $-0.103^{*}$ \\
\hline $\begin{array}{l}\text { Intention to avoid } \\
\text { food loss }\end{array}$ & -0.27 & 1.87 & -0.006 & -0.63 & 2.20 & -0.014 & 0.09 & 2.07 & 0.002 \\
\hline $\begin{array}{l}\text { General risks of } \\
\text { food loss }\end{array}$ & -0.11 & 1.06 & -0.004 & 1.67 & 1.31 & 0.060 & 1.75 & 1.23 & 0.067 \\
\hline $\begin{array}{l}\text { Knowledge } \\
\text { related to food } \\
\text { loss }\end{array}$ & 0.40 & 2.68 & 0.007 & -2.58 & 3.17 & -0.043 & -0.44 & 3.03 & -0.008 \\
\hline $\begin{array}{l}\text { Trust in } \\
\text { authorities }\end{array}$ & 1.50 & 0.88 & 0.076 & $\mathrm{n} / \mathrm{a}$ & $\mathrm{n} / \mathrm{a}$ & $\mathrm{n} / \mathrm{a}$ & $\mathrm{n} / \mathrm{a}$ & $\mathrm{n} / \mathrm{a}$ & $\mathrm{m} / \mathrm{a}$ \\
\hline Price & 1.50 & 0.89 & 0.063 & 0.69 & 1.09 & 0.026 & 0.37 & 1.00 & 0.015 \\
\hline Model statistics & \multicolumn{3}{|c|}{$\begin{array}{l}R^{2}=0.42 ; F(13,428)=24.28 \\
p<0.001\end{array}$} & \multicolumn{3}{|c|}{$\begin{array}{l}R^{2}=0.33 ; F(12,412)=16.82 ; \\
p<0.001\end{array}$} & \multicolumn{3}{|c|}{$\begin{array}{l}R^{2}=0.32 ; F(12,424)=16.63 ; \\
p<0.001\end{array}$} \\
\hline
\end{tabular}

The results of the regression analyses for the three loss reduction scenarios are presented in Table 7. For scenario

A1, the acceptance of pesticides and the perceived risks related to the pesticide use were very strong predictors

of the preference for scenario A1. As expected, respondents with higher acceptance of pesticides against wire worms preferred scenario A1. Those respondents who perceived high risks related to the pesticide use did not prefer scenario A1. The general intention to avoid food loss, respondents' knowledge related to food loss and perceived risks related to food loss did not significantly impact their preference.

In the case of scenario A4, the acceptance of unwashed potatoes had a significant positive impact, the inconvenience a significant negative impact (respondents who thought that unwashed potatoes are more inconvenient than washed ones preferred A4 less than the other respondents) as well as the perceived risks related to the scenario. Again, respondents' general intention to avoid food loss, the perceived general risks, knowledge related to food loss, and price sensitivity did not play a significant role. 
Also for scenario A5, the linear regression analysis revealed that only the scenario-specific constructs had a significant impact on the preference for the scenario (acceptance of the scenario had a positive impact, whereas higher perceived inconvenience and higher perceived risks concerning the scenario negatively influenced respondents' preference). The general intention to avoid food loss, perceived general risks, knowledge related to food loss and price sensitivity did not impact respondents' preference for scenario A5.

\section{Discussion}

\subsection{Implications for food loss reduction}

We observed significant socio-economic improvements for the scenarios A1 (pesticide against wire worms), A2 (improved quality sorting at farms), A4 (selling unwashed potatoes in a lightproof box) and the combined scenario (Mix) in relation to the current situation that exceeded the environmental benefits. No trade-offs were found between environmental and socio-economic indicators as negative impacts of several measures in a scenario could be compensated by an increased efficiency (e.g., although the pesticides against wire worms strain the environment and cause expenses, the efficiency increases because fewer potatoes have to be cultivated, harvested and traded to finally consume $1 \mathrm{~kg}$ of them). These results agree with those of other studies for various supply chains (De Boer and Cornelissen, 2002; van Asselt et al., 2014). Nonetheless, we found that not all loss reduction scenarios lead to environmental and socio-economic improvements. The results of the sustainability assessment imply that scenario A3 (no quality sorting at farms) could be rejected, as this scenario is not sustainable from a socio-economic perspective. Even if losses might decrease, more potatoes need to be transported and stored at wholesalers, which causes additional cost but no additional return. Although A2 scored worse than A3 on the environmental indicators (just slightly), its socio-economic performance was considerably better for all observed attributes. Consumers might not care whether the quality level is achieved by intensively sorting at farm stage or at wholesaler stage. Thus, in the Swiss context, sorting out potatoes with insufficient quality as early as possible is more sustainable, even if we consider potential utilizations of potato losses. The reason is that in Switzerland, most of the farms include animal husbandry (BFS, 2015b) and can therefore directly use the potato losses as animal feed. From a previous study (Willersinn et al., 2016) we know that feeding potato losses to animals results in considerable environmental benefits as several parts of a feed ration could be substituted. In another context, for example when potato growers mostly do not have any utilizations for potato losses, sorting at stages further down the chain might prove to be more suitable if potential loss treatments were integrated in the sustainability assessment. 
The sustainability performance of scenario A5 (selling unpacked potatoes) was similar to the current situation, the total loss rate being reduced only from $53 \%$ to $51 \%$. According to the consumer survey, respondents showed the highest preference for this scenario (compared with preferences for A1 and A4). Against this background, scenario A5 seems feasible, albeit not extremely efficient. It seems more favorable if we consider potential loss treatments. As losses occur earlier in the supply chain (fewer losses at private households; higher loss rate at retailer stage), fewer potatoes need to be transported to private households in vain, which saves monetary and environmental resources, and large loss quantities might be collected by retailers and used as animal feed or in a biogas plant.

Respondents of the consumer survey also signaled their acceptance of scenario A4. Due to an improved socioeconomic performance, the overall sustainability of this scenario compared with the reference situation was better, and the total loss rate decreased from $53 \%$ to $48 \%$. In this scenario, we assume that fewer losses occur at wholesaler stage but losses increase at household stage. However, this might have negative impacts if we consider potential loss treatments because losses at private households mainly end up in the residual waste, whereas losses at wholesalers are used as animal feed or in a biogas plant.

Respondents of the online survey did not prefer scenario A1 even though losses can be reduced considerably. This scenario scored well on our sustainability assessment but it seems not realizable as consumers strictly refuse the additional pesticide use due to perceived health risks related to this measure. From this circumstance, we can also assume that people would not accept the combined scenario (Mix) because scenario A1 is part of that scenario.

\subsection{Consumers' acceptance of loss reduction scenarios}

The theoretical model (Figure 4) that analyzed which factors impact the preference for a loss reduction scenario worked very well to explain respondents' preferences. Regression analyses showed that mainly the scenariospecific constructs (acceptance of the scenario, perceived inconvenience and perceived risks related to the scenario) are strong predictors of respondents' preferences. Besides the acceptance of the scenario itself, the perceived risks related directly to the scenario influenced respondents' preference. Respondents generally signaled high intention to avoid food loss (Stancu et al., 2016; Visschers et al., 2016) but not at all costs. People do, for example, not want to risk their health even if they hold negative personal norms and attitudes regarding food waste (Visschers et al., 2016).

Besides the acceptance of a specific scenario and the perceived scenario-specific risks, inconvenience significantly influenced those loss reduction scenarios that involved consumers (A4: selling unwashed potatoes 
in a lightproof box; A5: selling unpacked potatoes). Other studies also found that perceived inconvenience influences food loss behavior (Cox et al., 2010; Graham-Rowe et al., 2014; Thyberg and Tonjes, 2016).

Knowledge related to food loss correlated with the preference for a specific loss reduction scenario, but this predictor was not significant in the regression analyses and, thus, might be controlled for by other variables. Richter and Bokelmann (2016) stated that we have to distinguish between different types of knowledge that interact with various behaviors. In our study, we evaluated the knowledge about storage and use-by dates as this practical knowledge seems to be related to several behaviors. Stancu et al. (2016) found that procedural knowledge is related to consumers' routines regarding food choice and food wastage. These routines then might influence consumers' loss behavior and thus may influence the acceptance of loss reduction scenarios, especially if people have to change their routines accordingly.

\subsection{Strengths and limitations}

The broad view of the environmental, the socio-economic and the consumer perspectives enables stakeholders and decision-makers to consider several advantages and disadvantages of loss reduction. We did not directly include the consumer perspective into the SustainOS rating because consumers' acceptance and preferences cannot be compensated by socio-economic or environmental benefits that might occur at earlier stages of the supply chain. For example, if consumers do not accept an additional pesticide against wire worms even if losses decrease considerably, this cannot be compensated by a higher profitability. Thus, consumer acceptance can be seen as a criterion for exclusion.

In addition, some limitations need to be addressed. First, the generalizability of the consumer study might be limited to Switzerland, because our study was only carried out there. For example, within the survey people clearly indicated their refusal of loss reduction scenarios including an additional pesticide application. This might not be the case in every geographical region. In Switzerland, the share of organic consumption per capita is the highest compared to all other European countries (FiBL, 2015) which could be an indicator that Swiss people might be particularly sensitive concerning synthetic pesticide use. Another limitation might pose the mode of data collection. Due to the use of quota samples within the online survey, the age structure of the entire sample is not similar to the average Swiss public (Federal Statistical Office, 2014) and might be a source of bias. On the other hand, quota sample have some clear advantages: the results between the samples are more comparable as the socio-demographic variables are more similar than within random samples. Consequently, we can be even more confident that there are no significant differences between the three age groups or due to the gender which might be caused by discrepancies in socio-demographic factors (Siegrist et al., 2015). 
Thirdly, our study did not consider potential price changes due to the application of a loss reduction scenario.

We do not know whether prices would change if potatoes were sold unwashed or unpacked. Furthermore, we do not know at which stage of the supply chain prices would change. Also, the prices of qualitatively insufficient potatoes might increase if losses decrease. Price reductions would significantly decrease the profitability of the assessed scenarios. However, this is not a specific problem of this particular study. Price volatility affects almost all socio-economic assessments, and assumptions concerning prices are inevitable. In addition, we did not consider potential benefits from loss treatments because the focus of our study was on loss reduction and not on loss treatment. In the context of Switzerland, most potato losses are used as animal feed or to produce energy, while in other countries, they might remain on the fields or be landfilled.

\section{Conclusions}

When we try to reduce potato losses along the entire supply chain through various scenarios, we need to consider the environmental, the socio-economic and the consumer perspectives simultaneously because they might not be in line with each other. In a previous study (Willersinn et al., 2016) we investigated food loss just from the environmental perspective as many recently published studies did (e.g. Corrado et al. (2016); Eriksson et al. (2015); Scholz et al. (2015)). According to the life cycle impact assessment (LCIA), the loss reduction scenarios A1 (pesticide against wire worms) and Mix (combination of loss reduction scenarios) promised improvements, so that decision-makers might prefer one of these two scenarios. The present study revealed that none of these environmentally favorable options would be a feasible choice: consumers clearly indicated their refusal of a scenario, where an additional pesticide is applied to reduce potato losses even if losses might be reduced considerably. The LCIA also revealed that scenario A3 (no quality sorting at farms) and A5 (selling unpacked potatoes) might improve the environmental performance of the entire supply chain slightly. But again, if we include the socio-economic and consumer perspective, these scenarios seem not to be feasible anymore due to a worse socio-economic performance. Although losses might be reduced and consumers are not affected by scenario A3 or even preferred scenario A5, it is questionable whether these scenarios could be implemented without socio-economic incentives. Consumers are also not affected by scenario A2 (improved quality sorting at farms) and, thus, might accept it. In this scenario, the environmental performance was similar to the current situation while the socio-economic sustainability scored better, but losses were not reduced. Therefore, it can only be seen as a modification to improve particularly the socio-economic performance in the reference situation. The most promising scenario A4 (selling unwashed potatoes in a lightproof box) reduced losses significantly (from $53 \%$ to $48 \%$ ), scored similarly on environmental aspects and performed better than the 
470 reference situation from a socio-economic perspective. In addition, consumers indicated their preference for this 471 scenario if it reduces losses to the stated extent. These results show that looking just from one or two of these 472 perspectives might lead to unfavorable decisions. At least, there needs to be a general acceptance of the changes on the consumer side, and the perceived risks and inconveniences related to a specific scenario need to be small.

\section{Acknowledgements}

475 We thank the Swiss National Science Foundation (SNSF) for the financial support within the National Research Programme 69 (NRP 69) and all organizations and contact people for delivering information. 
Agridea, FiBL, 2015. Deckungsbeiträge 2015, Lindau, Schweiz.

Akkerman, R., Donk, D.P.v., 2008. Development and application of a decision support tool for reduction of product losses in the food-processing industry. Journal of Cleaner Production 2008, 335-342.

Beretta, C., Stoessel, F., Baier, U., Hellweg, S., 2012. Quantifying food losses and the potential for reduction in Switzerland. Waste Management 33, 764-773.

BFE, 2015. Strompreise 2016: Stabile Tarife für Haushalte und leichte Reduktion für mittlere Betriebe. Bundesamt für Energie BFE.

BFS, 2005. Transportrechnung Jahr 2005. Bundesamt für Statistik BFS, Neuchâtel.

BFS, 2015a. Mobilität und Verkehr, Taschenstatistik 2015. Bundesamt für Statistik BFS, Neuchâtel. BFS, 2015b. Schweizer Landwirtschaft - Taschenstatistik 2015. Bundesamt für Statistik, Neuchâtel.

BFS, 2016. Räumliche Verteilung: Agglomerationen, Stadt und Land. Bundesamt für Statistik, Neuchâtel.

Bockstaller, C., Guichard, L., Makowski, D., Aveline, A., Girardin, P., Plantureux, S., 2008. Agri-environmental indicators to assess cropping and farming systems. A review. Agronomy for Sustainable Development 28, 139149.

Corrado, S., Ardente, F., Sala, S., Saouter, E., 2016. Modelling of food loss within life cycle assessment: From current practice towards a systematisation. Journal of Cleaner Production in press.

Cox, J., Giorgi, S., Sharp, V., Strange, K., Wilson, D.C., Blakey, N., 2010. Household waste prevention - a review of evidence. Waste Management \& Research 28, 193-219.

De Boer, I.J.M., Cornelissen, A.M.G., 2002. A Method Using Sustainability Indicators to Compare Conventional and Animal-Friendly Egg Production Systems. Poultry Science 81, 173-181.

de Lange, W., Nahman, A., 2015. Costs of food waste in South Africa: Incorporating inedible food waste. Waste Management, 167-172.

Eriksson, M., Strid, I., Hansson, P.-A., 2015. Carbon footprint of food waste management options in the waste hierarchy e a Swedish case study. Journal of Cleaner Production 93, 115-125.

FAO, 2013. Food wastage footprint: Impacts on natural resources, Summary Report. Food and Agriculture Organisation of the United Nations, Rome.

FAO, 2015. FAOSTAT - Production/Crops. Food and Agriculture Organization of the United Nations.

Federal Statistical Office, 2014. Sustainable Development, Pocket Statistics 2014. Bundesamt für Statistik BfS, Neuchâtel.

FiBL, 2015. Key data on organic agriculture. Research Institute of Organic Agriculture.

Garnett, T., 2011. Where are the best opportunities for reducing greenhouse gas emissions in the food system (including the food chain)? Food Policy 36, 23-32.

Giuseppe, A., Mario, E., Cinzia, M., 2014. Economic benefits from food recovery at the retail stage: An application to Italian food chains. Waste Management 2014, 1306-1316.

Graham-Rowe, E., Jessop, D.C., Sparks, P., 2014. Identifying motivations and barriers to minimising household food waste. Resources, Conservation and Recycling 84, 15-23.

Heger, M., Robin, F., Heck, W., 2010. GOLDOR BAIT® - Ein neues Ködergranulat zur Bekämpfung von Drahtwürmern in verschiedenen Kulturen, Humboldt-Universität Berlin.

ISO 14040, 2006. Environmental management - Life cycle assessment - Principles and framework.

Katajajuuri, J.-M., Silvennoinen, K., Hartikainen, H., Heikkilä, L., Reinikainen, A., 2014. Food waste in the Finnish food chain. Journal of Cleaner Production 73, 322-329.

Keiser, A., Häberli, M., Schnyder, E., Berchier, P., 2007. Einfluss des Anbausystems, der Anbautechnik und des Standorts auf die Kartoffelqualität in der Schweiz. Schweizerische Hochschule für Landwirtschaft (SHL), CH3052 Zollikofen.

Keiser, A., Häberli, M., Stamp, P., 2012. Quality deficiencies on potato (Solanum tuberosum L.) tubers caused by Rhizoctonia solani, wireworms (Agriotes ssp.) and slugs (Deroceras retic-ulatum, Arion hortensis) in different farming systems. Field Crops Research 147-155.

Kranert, M., Hafner, G., Barabosz, J., Schuller, H., Leverenz, D., Kölbig, A., Schneider, F., Lebersorger, S., Scherhaufer, S., 2012. Ermittlung der weggeworfenen Lebensmittelmengen und Vorschläge zur Verminderung der Wegwerfrate bei Lebensmitteln in Deutschland. Universität Stuttgart, Institut für Siedlungswasserbau, Wassergüte- und Abfallwirtschaft, Stuttgart.

Laroche, M., Bergeron, J., Barbaro-Forleo, G., 2001. Targeting consumers who are willing to pay more for environmentally friendly products. Journal of Consumer Marketing 18, 503-520.

Migros, 2015. Jahresrechnung Migros-Genossenschafts-Bund, Finanzielle Berichterstattung 2014. MigrosGenossenschafts-Bund, Zürich.

Mouron, P., Calabrese, C., Breitenmoser, S., Spycher, S., Baur, R., 2016. Sustainability Assessment of Plant Protection Strategies in Swiss Winter Wheat and Potato Production. Agriculture 6.

Mouron, P., Heijne, B., Naef, A., Strassemeyer, J., Hayer, F., Avilla, J., Alaphilippe, A., Höhn, H., Hernandez, J., Mack, G., Gaillard, G., Solé, J., Sauphanor, B., Patocchi, A., Samietz, J., Bravin, E., Lavigne, C., Bohanec, 
M., Golla, B., Scheer, C., Aubert, U., Bigler, F., 2012. Sustainability assessment of crop protection systems: SustainOS methodology and its application for apple orchards. Agricultural Systems 113, 1-15.

Nemecek, T., Huguenin-Elie, O., Dubois, D., Gaillard, G., 2005. Ökobilanzierung von Anbausystemen im Schweizerischen Acker- und Futterbau, Schriftenreihe der FAL. Agroscope FAL Reckenholz, Zürich.

Richter, B., Bokelmann, W., 2016. Approaches of the German food industry for addressing the issue of food losses. Waste Management 48, 423-429.

Sadok, W., Angevin, F., Bergez, J.-E., Bockstaller, C., Colomb, B., Guichard, L., Reau, R., Messéan, A., Doré, T., 2009. MASC, a qualitative multi-attribute decision model for ex ante assessment of the sustainability of cropping systems. Agronomy for Sustainable Development 29, 447-461.

Scholz, K., Eriksson, M., Strid, I., 2015. Carbon footprint of supermarket food waste. Resources, Conservation and Recycling 94, 56-65.

Siegrist, M., Shi, J., Giusto, A., Hartmann, C., 2015. Worlds apart. Consumer acceptance of functional foods and beverages in Germany and China. Appetite 92, 87-93.

Sonesson, U., Janestad, H., Raaholt, B., 2003. Energy for Preparation and Storing of Food-Models for Calculation of Energy Use for Cooking and Cold Storage in Households, SIK-Report. SIK-The Swedish Institute for Food and Biotechnology, Göteborg, Sweden.

Stancu, V., Haugaard, P., Lähteenmäki, L., 2016. Determinants of consumer food waste behaviour: Two routes to food waste. Appetite 96, 7-17.

Stuart, T., 2009. Waste - uncovering the global food scandal. W W Norton \& Co London.

Swisspatat, 2013. Schweizerische Handelsusanzen für Kartoffeln.

Swisspatat, 2015. Statistische Angaben 2015 über Kartoffelbau und Kartoffelverwertung.

Thyberg, K.L., Tonjes, D.J., 2016. Drivers of food waste and their implications for sustainable policy development. Resources, Conservation and Recycling 106, 110-123.

van Asselt, E.D., van Bussel, L.G.J., van der Voet, H., van der Heijden, G.W.A.M., Tromp, S.O., Rijgersberg, H., van Evert, F., Van Wagenberg, C.P.A., van der Fels-Klerx, H.J., 2014. A protocol for evaluating the sustainability of agri-food productionsystems - A case study on potato production in peri-urban agriculturein The Netherlands. Ecological Indicators 43, 315-321.

Venkat, K., 2011. The climate change and economic impacts of food waste in the United States. International Journal on Food System Dynamics 2, 431-446.

Visschers, V.H.M., Wickli, N., Siegrist, M., 2016. Sorting out food waste behaviour: A survey on the motivators and barriers of self-reported amounts of food waste in households. Journal of Environmental Psychology 45, 6678.

Willersinn, C., Mack, G., Mouron, P., Keiser, A., Siegrist, M., 2015. Quantity and quality of food losses along the Swiss potato supply chain: Stepwise investigation and the influence of quality standards on losses. Waste Management 46, 120-132.

Willersinn, C., Möbius, S., Mouron, P., Lansche, J., Mack, G., 2016. Environmental impacts of food losses along the entire Swiss potato supply chain - current situation and reduction potentials. Journal of Cleaner Production in press.

WRAP, 2012. Reducing supply chain and consumer potato waste., Final Report. WRAP.

WWF, 2014. Lebensmittelverluste bei Fleisch, Gemüse und Brot. WWF Schweiz, Zürich.

Zorn, A., 2014. Vollkosten wichtiger Schweizer Ackerbaukulturen, 37. Informationstagung Agrarökonomie. Agroscope, Institut für Nachhaltigkeitswissenschaften INH, Tänikon 1, Ettenhausen, Schweiz.

\section{Appendix}

Table A1: Questionnaire items per construct, means $(M)$, standard deviations $(S D)$ and corrected item-total correlation $\left(\mathrm{r}_{\text {pbis }}\right)$ per item as well as internal reliability (Cronbach's $\alpha$ ), $M$ and SD of the construct.

\begin{tabular}{|c|c|c|c|}
\hline & $\mathrm{M}$ & SD & $r_{\text {pbis }}$ \\
\hline \multicolumn{4}{|l|}{ Intention to avoid food loss (Cronbach's $\alpha=0.866 ; N=6 ; \mathrm{M}=1.45 ; \mathrm{SD}=0.586$ ) } \\
\hline It is important to me that no food is wasted & 1.47 & 0.82 & 0.676 \\
\hline It is important to me that all purchased foods will be eaten & 1.42 & 0.71 & 0.701 \\
\hline I always try to waste no food at all & 1.41 & 0.69 & 0.686 \\
\hline I aim to use all leftovers & 1.58 & 0.81 & 0.668 \\
\hline I think that wasting food is a waste of money & 1.46 & 0.76 & 0.627 \\
\hline I feel bad when food is thrown away & 1.42 & 0.79 & 0.630 \\
\hline \multicolumn{4}{|l|}{ General risks of food loss (Cronbach's $\alpha=0.547 ; N=2 ; \mathrm{M}=3.68 ; \mathrm{SD}=0.937$ ) } \\
\hline I believe there is a risk of becoming ill as a result of eating potatoes that do not look perfect (anymore) & 3.44 & 1.14 & 0.376 \\
\hline Potato leftovers should not be served again & 3.91 & 1.12 & 0.376 \\
\hline \multicolumn{4}{|l|}{ Acceptance of scenario A1 (Cronbach's $\alpha=0.738 ; N=3 ; \mathrm{M}=3.90 ; \mathrm{SD}=0.858$ ) } \\
\hline I appreciate an additional use of pesticides if it results in reduced losses & 3.73 & 1.09 & 0.662 \\
\hline I will not accept additional pesticides at agricultural production* & 3.90 & 1.03 & 0.465 \\
\hline
\end{tabular}


I appreciate an additional chemical pest control to reduce losses even if it might harm the environment

4.06

Inconvenience of scenario A1 (Cronbach's $\alpha=0.513 ; N=3 ; \mathrm{M}=3.88 ; \mathrm{SD}=0.731$ )

I appreciate that I do not have to do anything for loss reduction

I do not care about this measure as it does not affect my household

inplementing measures to reduce losses that involve consumers

Perceived pesticide risks (Cronbach's $\alpha=0.540 ; N=3 ; \mathrm{M}=1.93 ; \mathrm{SD}=0.689$ )

I prefer implementing measures to reduce losses that bear fewer risks for the environment

$\begin{array}{lll}1.56 & 0.78 \quad 0.363\end{array}$

I am concerned that the additional pesticide might be harmful to me

$\begin{array}{lll}1.88 & 1.02-0.352\end{array}$

The loss reduction is not big enough for the increased environmental risk

2.34

I do not want to buy unwashed potatoes*

I would buy unwashed potatoes if consequently losses decreased

1.05

I would mind if tuber defects were hidden by the soil*

$1.98 \quad 1.16 \quad 0.479$

$\begin{array}{lll}1.98 & 1.06 & 0.436\end{array}$

$\begin{array}{lll}3.03 & 1.15 & 0.586\end{array}$

It is important to me that I can see the potatoes before buying. Thus, I would not buy potatoes in a non- $3.22 \quad \begin{array}{lll}1.21 & 0.589\end{array}$

transparent package*

I would buy unwashed potatoes in a non-transparent paperboard box if consequently losses decreased $\quad 2.27 \quad 1.12 \quad 0.597$

Loss reduction should be achieved by other measures*

Inconvenience of scenario A4 (Cronbach's $\alpha=0.677 ; N=5 ; \mathrm{M}=3.35 ; \mathrm{SD}=0.719$ )

I would not be happy if I had to wash potatoes myself

I do not like the described measure as mainly wholesalers and retailers would profit from fewer losses

The lightproof paperboard box makes storage easier*

The described measure limits me too much

4.09

1.09

$\begin{array}{lll}3.03 & 1.06 & 0.440\end{array}$

3.03

$\begin{array}{lll}3.42 & 1.14 & 0.377 \\ 3.57 & 1.10 & 0.563\end{array}$

Farmers, wholesalers and retailers should bother to reduce losses

2.62

Perceived risks of scenario A4 (Cronbach's $\alpha=0.571 ; N=2 ; \mathrm{M}=3.80 ; \mathrm{SD}=0.906$ )

I have concerns that unwashed potatoes might be harmful to my health

I guess that the described measure is just an attempt to sell low-grade potatoes

Acceptance of scenario A5 (Cronbach's $\alpha=0.695 ; N=3 ; \mathrm{M}=1.75 ; \mathrm{SD}=0.750$ )

I would not mind buying unpacked potatoes

I would buy unpacked potatoes if consequently losses decreased

I would appreciate selecting potatoes myself

Inconvenience of scenario A5 (Cronbach's $\alpha=0.747 ; N=5 ; \mathrm{M}=3.83 ; \mathrm{SD}=0.724$ )

Packing and weighing potatoes myself would cost me valuable time

I would be glad if I could help reduce potato losses through the described measure*

I would prefer packed potatoes as they are less complicated during shopping even if more losses occurred

The described measure limits me too much

Loss reduction should be achieved by other measures

$\begin{array}{lll}4.11 & 1.05 & 0.401\end{array}$

$\begin{array}{lll}4.11 & 1.05 & 0.401 \\ 3.47 & 1.11 & 0.401\end{array}$

3.47

$1.67 \quad 1.00$
0.401 statement.

Table A2: Items related to the general food loss knowledge, including the mean (M) and the standard deviation (SD) per item.

Knowledge index $(N=11 ; \mathrm{M}=2.07 ; \mathrm{SD}=0.426)$

Unprepared fresh potatoes should always be stored in the refrigerator*

Fresh potatoes that have been purchased more than 2 weeks ago should be disposed even if they still look fine*

Fresh potatoes that have passed their use-by date should be disposed in any case*

Households that plan their shopping trips purposefully waste less food than households that do not plan food purchases

Fresh potatoes should be stored in the dark

Green spots on potatoes should be at least cut off

Someone who buys smaller amounts of food wastes less food

Light makes the potatoes turn green and speed up the aging

Unwashed potatoes have a longer shelf life than washed potatoes

Private households waste very few fresh potatoes*

Food production and supply harm the environment considerably

$\begin{array}{lll}1.62 & 0.90 & 0.525\end{array}$

$\begin{array}{lll}1.96 & 0.96 & 0.496\end{array}$

$\begin{array}{lll}4.11 & 1.04 & 0.599\end{array}$

$\begin{array}{lll}4.29 & 0.89 & 0.415\end{array}$

$\begin{array}{lll}3.57 & 1.12 & 0.582\end{array}$

$\begin{array}{lll}3.14 & 0.98 & 0.612\end{array}$

$3.04 \quad 1.08 \quad 0.368$

Note: *Item is incorrect, which means that responses were reversed to indicate correct and incorrect answers. All items were assessed on a 5-point Likert scale; lower values correspond to stronger agreement with the statement.

Table A3: Pearson correlation coefficients for psychological constructs and the preference for loss reduction scenario Al 588 (pesticides against wire worms).

\begin{tabular}{|c|c|c|c|c|c|c|c|c|c|}
\hline Variable & 1. & 2. & 3. & 4. & 5. & 6. & 7. & 8. & 9. \\
\hline 1. Preference for scenario A1 & 1.00 & & & & & & & & \\
\hline 2. Acceptance of pesticides & $0.61 * *$ & 1.00 & & & & & & & \\
\hline 3. Inconvenience & $0.34 * *$ & $0.54 * *$ & 1.00 & & & & & & \\
\hline 4. Perceived pesticide risks & $-0.44 * *$ & $-0.54 * *$ & $-0.37 * *$ & 1.00 & & & & & \\
\hline 5. Intention to avoid food loss & $-0.13 * *$ & $-0.18 * *$ & $-0.28 * *$ & $0.24 * *$ & 1.00 & & & & \\
\hline 6. General risks of food loss & $0.16^{* *}$ & $0.26^{* *}$ & $0.32 * *$ & $-0.11^{*}$ & $-0.27 * *$ & 1.00 & & & \\
\hline 7. Knowledge related to food loss & $-0.21 * *$ & $-0.31 * *$ & $-0.41 * *$ & $0.28 * *$ & $0.52^{* *}$ & $-0.41 * *$ & 1.00 & & \\
\hline 8. Trust in authorities & $0.40 * *$ & $0.55 * *$ & $0.31 * *$ & $-0.36^{* *}$ & -0.09 & $0.12 * *$ & $-0.15 * *$ & 1.00 & \\
\hline 9. Price & -0.09 & $-0.11^{*}$ & -0.08 & 0.03 & -0.02 & -0.05 & 0.05 & -0.08 & 1.00 \\
\hline
\end{tabular}

$* p<0.05 ; * * p<0.01$ 
Table A4: Pearson correlation coefficients for psychological constructs and the preference for loss reduction scenario A4 (selling unwashed potatoes in a lightproof box).

\begin{tabular}{|l|l|l|l|l|l|l|l|l|}
\hline Variable & 1. & 2. & 3. & 4. & 5. & 6. & 7. & 8. \\
\hline 1. Preference for scenario A4 & 1.00 & & & & & & & \\
\hline 2. Acceptance of unwashed potatoes & $0.51^{* *}$ & 1.00 & & & & & & \\
\hline 3. Inconvenience & $-0.53^{* *}$ & $-0.75^{* *}$ & 1.00 & & & & & \\
\hline 4. Perceived risks of the scenario & $-0.45^{* *}$ & $-0.68^{* *}$ & $0.66^{* *}$ & 1.00 & & & & \\
\hline 5. Intention to avoid food loss & 0.09 & $0.22^{* *}$ & $-0.21^{* *}$ & $-0.21^{* *}$ & 1.00 & & & \\
\hline 6. General risks of food loss & $-0.13^{* *}$ & $-0.35^{* *}$ & $0.32^{* *}$ & $0.39^{* *}$ & $-0.27^{* *}$ & 1.00 & & \\
\hline 7. Knowledge related to food loss & $0.17^{* *}$ & $0.32^{* *}$ & $-0.37^{* *}$ & $-0.41^{* *}$ & $0.52^{* *}$ & $-0.41^{* *}$ & 1.00 & \\
\hline 8. Price & -0.06 & $-0.15^{* *}$ & $0.11^{*}$ & $0.14^{* *}$ & -0.02 & 0.05 & -0.05 & 1.00 \\
\hline
\end{tabular}

591

Table A5: Pearson correlation coefficients for psychological constructs and the preference for loss reduction scenario A5 (selling unpacked potatoes).

\begin{tabular}{|l|l|l|l|l|l|l|l|l|}
\hline Variable & 1. & 2. & 3. & 4. & 5. & 6. & 7. & 8. \\
\hline 1. Preference for scenario A5 & 1.00 & & & & & & & \\
\hline 2. Acceptance of unpacked potatoes & $0.48^{* *}$ & 1.00 & & & & & & \\
\hline 3. Inconvenience & $-0.52^{* *}$ & $-0.61^{* *}$ & 1.00 & & & & & \\
\hline 4. Perceived risks of the scenario & $-0.34^{* *}$ & $-0.37^{* *}$ & $0.52^{* *}$ & 1.00 & & & & \\
\hline 5. Intention to avoid food loss & $0.14^{* *}$ & $0.23^{* *}$ & $-0.24^{* *}$ & $-0.21^{* *}$ & 1.00 & & & \\
\hline 6. General risks of food loss & $-0.14^{* *}$ & $-0.24^{* *}$ & $0.35^{* *}$ & $0.38^{* *}$ & $-0.27^{* *}$ & 1.00 & & \\
\hline 7. Knowledge related to food loss & $0.20^{* *}$ & $0.28^{* *}$ & $-0.41^{* *}$ & $-0.33^{* *}$ & $0.52^{* *}$ & $-0.41^{* *}$ & 1.00 & \\
\hline 8. Price & -0.05 & -0.03 & $0.13^{* *}$ & 0.08 & 0.02 & 0.05 & -0.05 & 1.00 \\
\hline
\end{tabular}




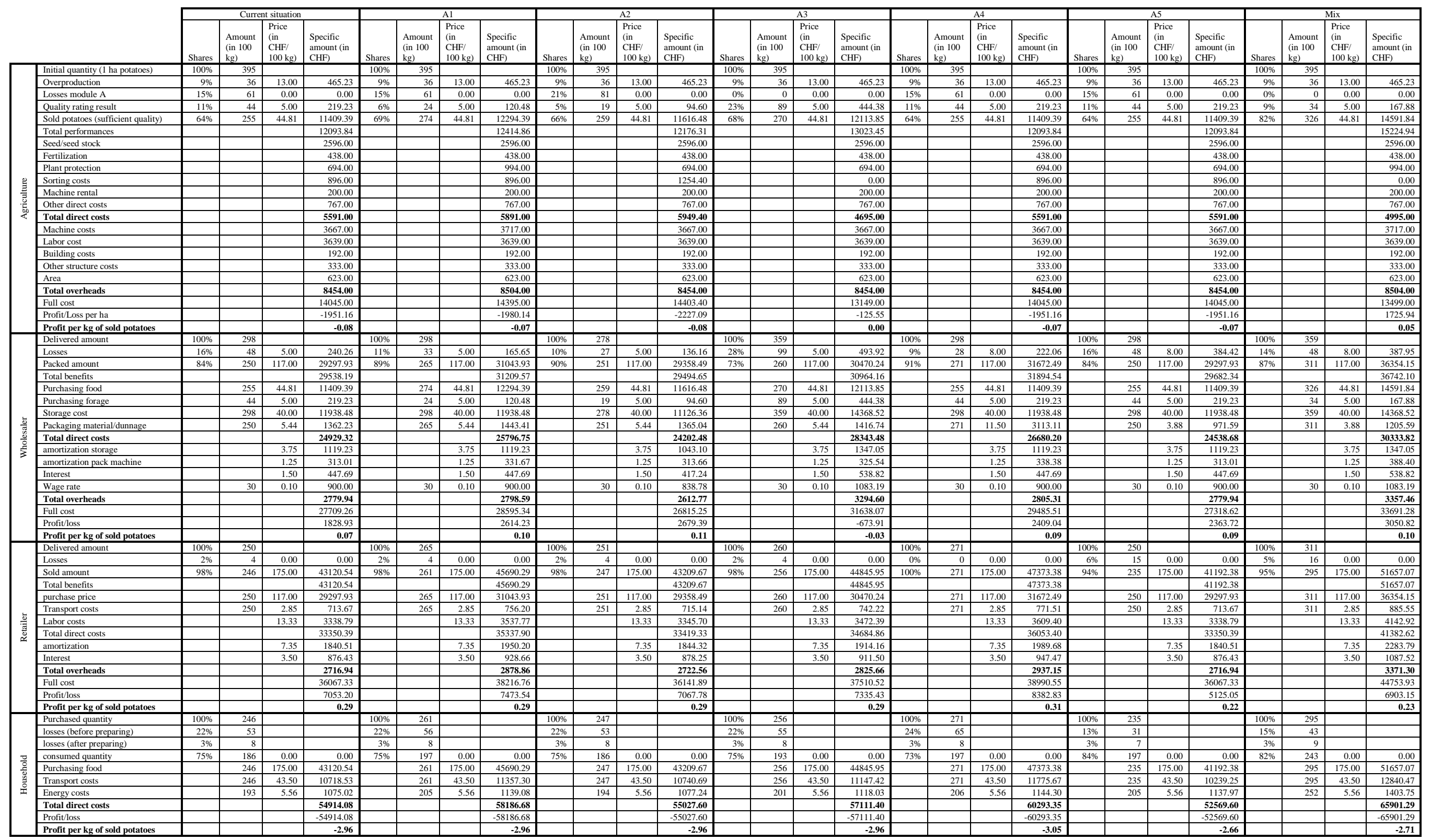

